\title{
Electrotonic Synapses Between Aplysia Neurons in situ and in Culture: Aspects of Regulation and Measurements of Permeability
}

\author{
Rolf Bodmer, ${ }^{1, a}$ Vytas Verselis, ${ }^{1}$ Irwin B. Levitan, ${ }^{2}$ and David C. Spray ${ }^{1}$ \\ 'Department of Neuroscience, Albert Einstein College of Medicine, Bronx, New York 10461, and ${ }^{2}$ Graduate Department of \\ Biochemistry, Brandeis University, Waltham, Massachusetts 02254
}

Properties of electrotonic synapses between L14 neurons in the abdominal ganglion of the marine mollusc Aplysia californica were examined in situ and between unidentified buccal neurons maintained in tissue culture. In culture, depolarizing postsynaptic potentials in response to a train of action potentials showed apparent facilitation with increasing spike number, which was attributable to the low-pass filter properties of electrotonic transmission via gap junctions and to network properties. Gap junctional conductance $\left(g_{j}\right)$, calculated from current-clamp data or measured directly under voltage clamp, indicated no significant dependence of $g_{j}$ on transjunctional or inside-outside potential in situ or in culture. Octanol, a local anesthetic agent that reduces $\boldsymbol{g}_{j}$ in many other systems, had no effect on $g$, between Aplysia neurons. The effect of intracellular acidification, a treatment that rapidly and reversibly uncouples a variety of cell types, reduced $g_{j}$ between Aplysia neurons but did not completely abolish it. The relationship between intracellular $\mathbf{p H}\left(\mathrm{pH}_{i}\right)$, measured with ion-sensitive microelectrodes, and $g_{i}$ was steeper in cultured neurons than in situ and was maximally reduced by $70-80 \%$, as compared to $50 \%$ or less in situ at the lowest $\mathrm{pH}_{\mathrm{i}}$ values tested. The coupling coefficient (k) was reduced less by low $\mathrm{pH}_{\mathrm{i}}$ than was $\mathrm{g}_{j}$, which could be explained by a simultaneous increase in nonjunctional membrane resistance. Permeability properties of Aplysia electrotonic synapses to a variety of tracer molecules were also examined between identified L14 neurons in situ and in dissociated buccal, abdominal, and bag neurons in culture. The fluorescent dyes Lucifer yellow, 6-carboxyfluorescein, and dichlorofluorescein (1.2-1.4 nm maximal diameters) did not spread detectably from an injected neuron to its electrically coupled neighbors, regardless of the strength of electrotonic coupling. However, the smaller tetraalkylammonium ions TMA and TEA (diameters 0.66 and $0.8 \mathrm{~nm}$, concentrations measured with ion-selective electrodes), could be detected in neighboring cells within minutes. In culture, transfer of the tetraalkylammonium ions was slow and not easily detectable in cell pairs where $g_{j}$ was low $(<20 \mathrm{nS})$. The permeability was as high as $10^{-10} \mathrm{~cm}^{3} / \mathrm{sec}$ in situ and $10^{-12} \mathrm{~cm}^{3} / \mathrm{sec}$ in

Received Jan. 16, 1987; revised Sept. 8, 1987; accepted Sept. 10, 1987

Supported in part by NSF Grant BNS-8400875 (to I.B.L.) and NIH Grants NS 16524 and NS 07512 (to D.C.S.)

Correspondence should be addressed to David C. Spray, Department of Neuroscience, Albert Einstein College of Medicine, 1300 Morris Park Avenue, Bronx, NY 10461.

aPresent address: Department of Physiology, University of California, School of Medicine, San Francisco, CA 94143.

Copyright $(\mathcal{C} 1988$ Society for Neuroscience $0270-6474 / 88 / 051656-15 \$ 02.00 / 0$ culture, and values were roughly correlated with simultaneously measured values of $g_{j}$. Electrotonic synapses in the nervous system of Aplysia, therefore, have a quantitatively different spectrum of sensitivities than has been found for gap junctions of other systems and appear to possess reduced permeability to tracer molecules.

Electrotonic synapses have been described between $A p l y s i a$ neurons, both in situ and in dissociated cells in culture (Waziri, 1969; Gillette and Pomeranz, 1975; Carew and Kandel, 1976; Gardner, 1977; Kaczmarek et al., 1979; Rayport and Kandel, 1980; Dagan and Levitan, 1981; Bodmer et al., 1984), but the properties of electrotonic synapses in this species have not been compared with those of other systems. On the basis of limited freeze-fracture electron microscopic studies on Aplysia (Kaczmarek et al., 1979; Porvaznik et al., 1979) and more extensive studies on other molluscan species (Hall et al., 1983; Roubos et al., 1985), the gap junction has been assigned as the structural basis for electrotonic coupling in the Aplysia nervous system, as it is in other excitable and inexcitable tissues (see Bennett and Spray, 1985). For gap junctions in general, a varicty of agents and treatments has been shown to affect junctional conductance $\left(g_{j}\right)$ (see Bennett and Spray, 1985; Spray and Bennett, 1985). Stimuli that act to close (or gate) gap junction channels include voltage, applied either across the junctional membrane or between the inside and outside of the cell (see Spray et al., 1985), cytoplasmic acidification (Turin and Warner, 1978; Spray et al., 1981 b), and extracellularly applied octanol (Johnston et al., 1980; Spray et al., 1985).

Intracellular $\mathrm{pH}\left(\mathrm{pH}_{\mathrm{i}}\right)$ can be varied by manipulation of the external media with weak acids or bases, which are membrane permeable in their undissociated forms (Roos and Boron, 1981) and by the addition of $\mathrm{CO}_{2}$ (Thomas, 1974). $\mathrm{CO}_{2}$, the most common treatment, has been reported to reduce electrotonic coupling in many different systems (Turin and Warner, 1978; Iwatsuki and Petersen, 1979; Giaume et al., 1980; Spray et al., 1981 b; Schuetze and Goodenough, 1982; Connors et al., 1984; see also Spray and Bennett, 1985). However, in some of those reports, evidence was presented that $\mathrm{CO}_{2}$ might have little or no effect on dye coupling (Schuetze and Goodenough, 1982; Connors et al., 1984). Preliminary results indicated a similar finding for electrotonic coupling among Aplysia neurons in situ and in culture (Bodmer, 1983).

Abdominal L14 ncurons, which are involved in Aplysia's inking behavior (Frazier et al., 1967; Kandel, 1976) show extensive electrotonic coupling (Carew and Kandel, 1976), as do cultured buccal neurons (Dagan and Levitan, 1981; Bodmer et al., 1984). 
In the present study, we investigate the properties of these electrotonic synapses using electrophysiological techniques, which allowed direct assessment of $g_{j}$ and $\mathrm{pH}_{\mathrm{i}}$ directly. We report here that in Aplysia neurons $g_{j}$ is not voltage dependent and is insensitive to octanol treatment but is reduced gradually with decreasing $\mathrm{pH}_{\mathrm{i}}$; block was incomplete at $\mathrm{pH}_{\mathrm{i}}$ values as low as 5.6. The coupling coefficient was frequently insensitive to low $\mathrm{pH}_{\mathrm{i}}$, and this finding is attributable to effects of weak acids on the resistance of the nonjunctional membrane. The sensitivity of Aplysia electrotonic synapses to these treatments is therefore different from that of gap junctions in many other systems.

Gap junctional membranes are also characterized by their permeability to fluorescent tracer molecules $(1.2-1.4 \mathrm{~nm}$ diameter). Injection of dye into one cell often leads to detectable spread to adjacent cells within minutes (e.g., Macagno et al., 1981; Schwartzmann et al., 1981; Knowles et al., 1982; Brenowitz et al., 1983; Margiotta and Walcott, 1983; Connors et al., 1984; Fraser and Bryant, 1985). Recently, junctional permeability to these and smaller probes has been assessed quantitatively in several preparations (e.g., Atkinson and Sheridan, 1985; Brink, 1985; Safranyos and Caveney, 1985; Verselis et al., 1986a, b).

In order to assess the permeability properties of Aplysia neuronal gap junctions, we examined whether the fluorescent dyes Lucifer yellow (LY), 6-carboxyfluorescein (6-CF), and dichlorofluorescein $\left(\mathrm{Cl}_{2} \mathrm{~F}\right)$ passed between electrotonically coupled $\mathrm{L} 14$ neurons in situ and between dissociated buccal and bag neurons in culture. Electrophysiological measurement simultaneously assessed the strength of electrotonic coupling. We found that the fluorescent probes were not detectably permeable even when $g_{j}$ was moderately high, but quantitative evaluation of very slow dye transfer was difficult because of low-level autofluorescence and cell pigmentation. We circumvented this difficulty by quantitative measurement of the intercellular flux of the smaller tetraalkylammonium ions tetramethylammonium (TMA) and tetraethylammonium (TEA) using ion-sensitive microelectrodes. Transfer of these probes was always readily detected between L14 neurons in situ but not between neurons in culture. This discrepancy is apparently related to $g_{j}$ values and is discussed with respect to results from other systems.

A preliminary account of this work has been presented previously (Bodmer and Spray, 1985).

\section{Materials and Methods}

Tissue culture. Aplysia buccal neurons and bag cells were cultured as previously described (Dagan and Levitan, 1981; Bodmer et al., 1984). Briefly, the neurons were mechanically dissociated and plated under sterile conditions in 35 or $60 \mathrm{~mm}$ culture dishes containing $1 \%$ methyl cellulose (Methocel, DOW) and 4\% fetal calf serum in L-15 medium (Gibco) supplemented with physiological salt concentrations. The culture dishes were incubated for 1-8 weeks at room temperature (19$23^{\circ} \mathrm{C}$ ) in a humidified chamber.

Perfusion conditions. Aplysia saline was prepared as described previously (Levitan and Barondes, 1974), except that 10 mM HEPES was used as a buffer; $\mathrm{pH}$ was adjusted to 7.4. $\mathrm{CO}_{2}$-saturated saline was obtained by vigorously bubbling the saline solution with $100 \% \mathrm{CO}_{2}$ before $(10 \mathrm{~min})$ and during its application to the cultures. The $\mathrm{pH}$ of saline equilibrated with $100 \% \mathrm{CO}_{2}$ was about 5.0 and could be partially compensated (to $\mathrm{pH} 6.5$ ) by raising the concentration of HEPES buffer to $50 \mathrm{~mm}$. $\mathrm{NH}_{4} \mathrm{Cl}$ (Sigma) was applied at 50 and $80 \mathrm{~mm}$ concentrations in saline. Octanol was prepared as a 5-10 mM suspension in saline and was shaken vigorously before adding to the preparation. Culture dishes were perfused on the stage of an inverted microscope (Nikon diaphot) at a flow rate of $0.5-2 \mathrm{ml} / \mathrm{min}$. For in situ recordings of L14 neurons, ganglia were chemically desheathed using $1 \%$ dispase (Boehringer), at $21^{\circ} \mathrm{C}$ overnight, were then pinned out in a Sylgard-containing dish and viewed through a Wild dissecting microscope.

Intracellular recordings. Individual neurons were impaled with microelectrodes $(5-20 \mathrm{M} \Omega$ ) filled with $3 \mathrm{M} \mathrm{KCl}$ or potassium citrate. The outputs of the FET input preamplifiers were displayed on a storage oscilloscope and a 4-channel pen recorder (Gould Instruments).

Current clamp. Cellular input resistances were determined by injecting pulses of inward (hyperpolarizing) current through the recording electrode. The voltage drop across the electrode was circumvented by a chopped current injection device (Almost Perfect Electronics, Basel). For measurements of electrotonic coupling, current pulses of $0.5-5 \mathrm{sec}$ were alternately delivered to each cell of the pair, and the resulting steady-state potential changes in both cells were measured.

Voltage clamp. For a single electrode voltage clamp, the electrode was alternately switched between the voltage measuring and current passing modes. $I-V$ curves were obtained by sweeping the voltage between 2 levels at a rate $(5 \mathrm{mV} / \mathrm{sec})$ much slower than the membrane time constant (Adams et al., 1980). Junctional conductance $\left(g_{i}\right)$ was measured by applying voltage command steps $\left(V_{1}\right)$ to one cell and measuring the resulting current in the other cell $\left(I_{2}\right) ; g_{j}=-I_{2} / V_{1}$ (Spray et al., 1981a). Alternatively, the potential was swept between 2 voltage levels in the first cell and the current change in the second voltage-clamped cell was measured at a fixed potential $\left(d V_{2}=0\right)$ (see Bennett, 1966).

Measurement of $p I_{\mathrm{i}}$. Intracellular $\mathrm{pH}$-sensitive microelectrodes were constructed from fiber-containing glass pulled as for conventional microelectrodes. Electrodes were silanized by filling the tip with $5 \%$ (vol/ vol) dichlorodimethyl silane (Fluka) dissolved in $\mathrm{CCl}_{4}$. Electrodes were baked in a vacuum oven at $200^{\circ} \mathrm{C}$ for $30 \mathrm{~min}$ and allowed to cool. Liquid ion-exchange resin ( $5 \mu \mathrm{l}$; Fluka) was used to fill the tips of the silanized electrodes and were then backfilled with $150 \mathrm{~mm} \mathrm{KCl}$ buffered to $\mathrm{pH} 7.0$ with $10 \mathrm{~mm}$ HEPES. Electrodes were calibrated in Aplysia physiological salines over the range 5.5-7.5 before and after experimental use; data were discarded if the calibration curves shifted by more than $0.1 \mathrm{pH}$ unit and slopes were $<50 \mathrm{mV} / \mathrm{pH}$ unit. Intracellular placement of the $\mathrm{pH}$-sensitive electrode was verified by the criterion of similar steady-state voltage responses in the $\mathrm{pH}$ and voltage electrodes in response to a long current pulse delivered to the other cell (see Campos dc Carvalho ct al., 1984; Spray ct al., 1986).

Intracellular dye injections. $\mathrm{LY}, 6-\mathrm{CF}$, and $\mathrm{Cl}_{2} \mathrm{~F}(2-4 \% \mathrm{wt} / \mathrm{vol}$ in water, fluorescein derivatives buffered to $\mathrm{pH} 7.8$ with $10 \mathrm{mM}$ HEPES) were intracellularly injected through separate electrodes by applying negative current pulses $(-2$ to $-20 \mathrm{nA}, 0.1-0.5 \mathrm{sec}$ duration, for $5-30 \mathrm{~min}$ at about $1 \mathrm{~Hz}$ ). TMA and TEA were intracellularly injected by applying pressure with a Picospritzer (General Valve Corp, Fairfield, NJ) to the back of electrodes filled with $1 \mathrm{M}$ solutions of the tetraalkylammonium ions buffered to $\mathrm{pH} 7.6$ with $10 \mathrm{mM}$ HEPES. Dye injections were monitored on a Nikon Diaphot microscope with xenon arc lamp illumination using epifluorescence optics with appropriate excitation and emission filters.

Tetraalkylammonium ion measurements. Ion-selective electrodes constructed with Corning $\mathrm{K}^{+}$exchange resin (477317) display a high selectivity for tetraalkylammonium ions over $\mathrm{K}^{+}$(Ohme and Simon, 1976). Techniques for use and construction of these electrodes is detailed elsewhere (Verselis et al., 1986b). Microelectrode responses to different concentrations of TMA and TEA were linear in the range of 1-100 mM, producing an approximately $60 \mathrm{mV}$ deflection per 10 -fold change in concentration (see calibration curves in Figs. 10, 11). All calibration solutions contained concentrations of the appropriate tetraalkylammonium ion ranging from $1 \mu \mathrm{M}$ to $100 \mathrm{mM}$ in $300 \mathrm{mM} \mathrm{KCl}(\mathrm{pH} 7.5)$ to simulate the intracellular environment of the cell. Ionic strength was adjusted to $500 \mathrm{~mm}$ with $\mathrm{NaCl}$.

Permeability values were obtained by injecting one cell of a pair with TMA or TEA and measuring changes in concentration in the injected (prejunctional) cell and recipient (postjunctional) cell over time. Transjunctional fiux $(J)$ was determined by multiplying the rate of change in TMA or TEA concentration in the postjunctional ccll $\left(d C_{2} / d t\right)$ by the volume $\left(v_{2}\right)$ of that cell so that:

$$
J=v_{2} d C_{2} / d t
$$

For these experiments, it was assumed that the cell volume was dominated by that of the soma, so that $v_{2}=4 \pi r^{3 / 3}$, where $r$ was measured using an eyepiece micrometer. Assuming no loss from the cells, the permeability $(P)$ was determined by dividing the flux $(J)$ by the driving force. For charged molecules such as TMA and TEA, the driving force is contributed by both concentration $(d C)$ and voltage $(d V)$ gradients, 


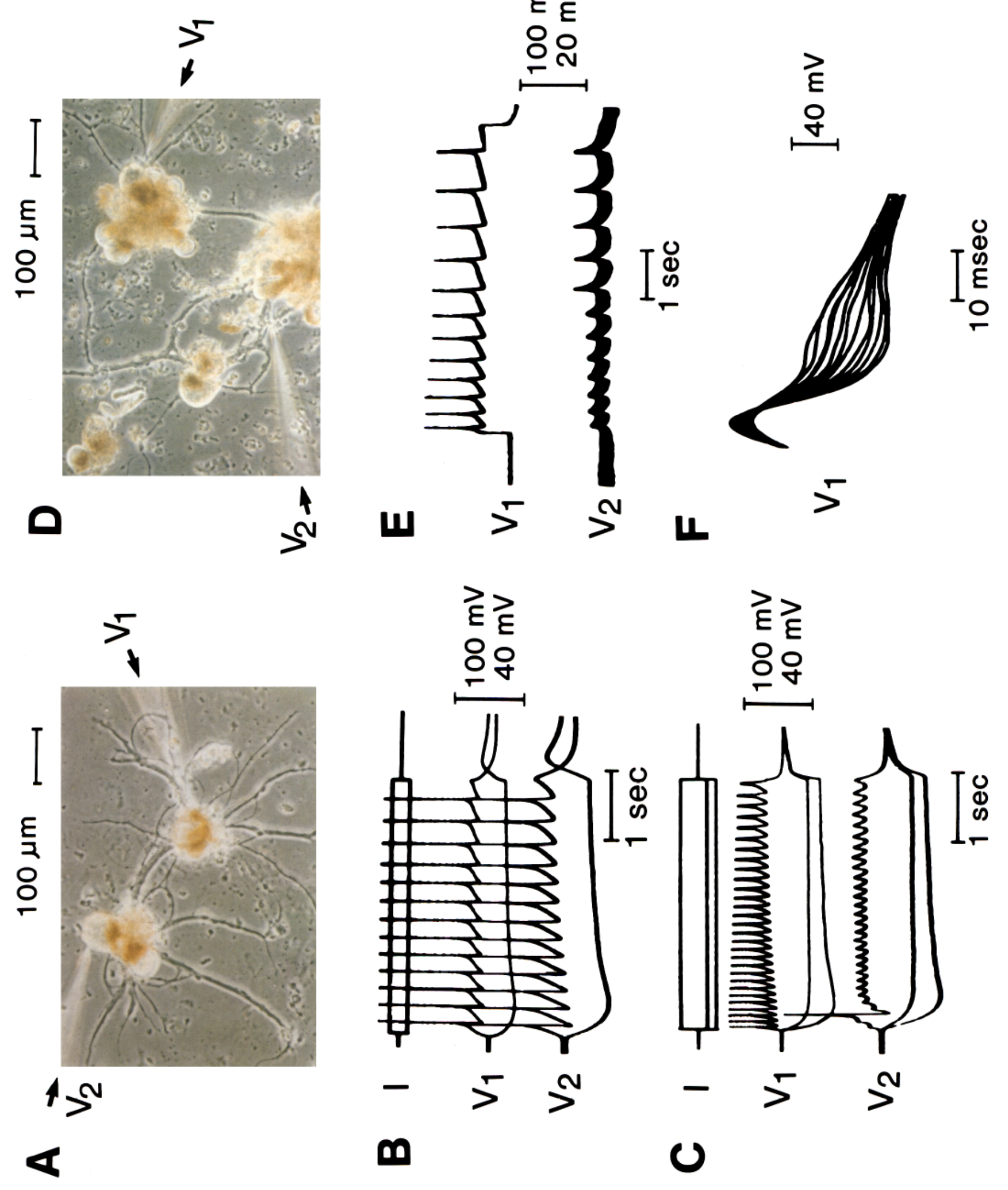


which for a constant field assumption (Goldman, 1943; Hodgkin and Katz, 1949) yields

$$
P=\frac{J[1-\exp (z F V / R T)]}{z F V / R T\left[C_{1}-C_{2} \exp (Z F V / R T)\right]}
$$

where $z$ is the valence, $R$ is the gas constant, $T$ is the temperature, $F$ is the Faraday constant, $V$ is the transjunctional voltage, and $C_{1}$ and $C_{2}$ are the concentrations in the pre- and postjunctional cells, respectively (see Verselis et al., 1986b). For cases in which the voltages of the 2 cells were the same, this equation simplifies to

$$
P=J /\left(C_{1}-C_{2}\right)
$$

\section{Results}

Electrotonic coupling $(\mathrm{k})$ and junctional conductance $\left(\mathrm{g}_{\mathrm{j}}\right)$

Aplysia buccal neurons in primary culture were previously shown to connect via electrotonic synapses with high frequency (Dagan and Lcvitan, 1981; Bodmcr ct al., 1984). Figure 1 demonstrates that these junctions may exhibit some apparently nonlinear properties either in pairs or in ensembles of several interconnected neurons. In a simple case (Fig. $1 B$ ), exciting a neuron $\left(V_{1}\right)$ resulted in a one-for-one transmission to the postsynaptic neuron. In some pairs of neurons, depolarizing current injection elicted a train of action potentials that decreased in height and increased in width during the train (Fig. $1 C$, trace $\mathrm{V}_{1}$ ), whereas the postsynaptic electrotonic potentials (psp) increased in width and height and only occasionally elicited action potentials (Fig. $1 C$, trace $\mathrm{V}_{2}$ ). Such behavior can be explained by the low-pass filter properties of the electrotonic synapse (Bennett, 1966): a short-duration spike will be attenuated much more than a broader one. In a complex network of neurons (as depicted in Fig. $1 D)$, the electrotonic transmission of spikes often exhibited a sudden increase in size of the psp superimposed on the smooth steady increase (arrow in trace $\mathrm{V}_{2}$, Fig. $1 E$ ). When the presynaptic train of spikes was examined at higher sweep speeds and superimposed, only a steady increase in width was observed (Fig. 1F). It was, therefore, concluded that this train of spikes eventually recruited another neuron in the network to fire, thereby contributing additively to the psp. To avoid these polysynaptic effects, only hyperpolarizing pulses were used in isolated pairs of cultured neurons with closely apposed somata (see Fig. $2 A$ ) analyzed to characterize electrical coupling (described below).

The strength of electrotonic transmission can be expressed by the coupling coefficient $(k)$, which is the ratio of the voltage deflection in the coupled cell ( $V_{1}$, first pulse Fig. $2 B$ ) to the voltage deflection in the cell in which current was injected $\left(V_{2}\right.$, first pulse in Fig. $2 B$ ). The conductance of the junctional membrane $\left(g_{j}\right)$ is expressed by dividing the current transferred to the coupled cell under voltage clamp $\left(I_{2}\right.$, when $\left.d V_{2}=0\right)$ by the voltage applied $\left(V_{1}\right)$. In Figure $2 C$, this measurement of $g_{j}$ is illustrated in the case of a voltage ramp delivered to the first cell $\left(V_{1}\right)$ while holding the second at a constant voltage (not shown). Alternatively, in current clamp $g_{j}$ can be calculated by applying the $\pi$-t transform with $k$ and the input resistances $\left(r_{11}\right.$, $r_{22}$ ) of both cells as variables (Bennett, 1966):

$$
\begin{aligned}
k_{1-2} & =V_{2} / V_{1}=r_{12} / r_{11} \quad\left(r_{12}: \text { transfer resistance }\right) \\
k_{1-2} & =1 /\left(1+1 / g_{j}\left(r_{11} r_{22}-r_{12}{ }^{2}\right) /\left(r_{11}-r_{12}\right)\right) \\
g_{j} & =k_{1-2} /\left(r_{22}-k_{12}{ }^{2} r_{11}\right) \text { and symmetrically } \\
g_{j} & =k_{2-1} /\left(r_{11}-k_{21}{ }^{2} r_{22}\right)
\end{aligned}
$$

Calculating $g_{j}$ from the measurements of Figure $2 B$ yielded $g_{j}=28$ or $30 \mathrm{nS}$ when applying equation (5) to $k_{1-2}$ or $k_{2-1}$, respectively. These values are close to those obtained from measuring $g_{j}$ with a voltage clamp in Figure $2 C$, where $g_{j}$ was $31 \mathrm{nS}$. In Figure $2 D$ the plot of $I_{2}$ versus $V_{1}$ (from the data of Fig. $2 C$ ) exhibits an approximately linear relationship [slope $\left(g_{j}\right)=31$ $\mathrm{nS}$ ], indicating that over this range of voltages $g_{j}$ was largely voltage independent.

Taken together, the behavior of this electrotonic synapse in culture suggests adequate voltage control of the pre- and postsynaptic membranes. Similar results were obtained from other pairs of coupled neurons in culture, when they were sufficiently isolated from other cells and closely apposed to one another. In some pairs where the $I-V$ curves of the individual cells were more nonlinear, the plots of $I_{2}$ versus $V_{1}$ still indicated linearity of the junctional membrane.

The results in culture were compared with those obtained from electrotonic synapses of L14 neurons in situ. L14 neurons (indicated schematically in Fig. $2 E$ ) were tightly coupled in situ $(0.4<k<0.7)$; e.g., in Figure $2 F, k$ was 0.5 . The value calculated for $g_{j}$ under current clamp was $370 \mathrm{nS}$, and the value measured for $g_{j}$ under voltage clamp was $480 \mathrm{nS}$ (Fig. $2 G$ ). In other L14 pairs the difference between measured and calculated values was even less, indicating that the efficacy of the space clamp was comparable to the experiments on cultured neurons. No significant dependence of $g_{j}$ on transjunctional potential was detectable in situ, as demonstrated in Figure $2 G$ (compare slopes of $I_{1}$ and $V_{2}$ traces). Varying holding potential over a wide range ( $\pm 40 \mathrm{mV}$ in Fig. 2, $C$ and $G$ ) also did not change $g_{j}$ appreciably, suggesting no dependence of $g_{j}$ on inside-outside potential.

\section{Octanol does not effect coupling between Aplysia neurons}

Figure 3 shows that there is no effect of octanol on $k$ or calculated $g_{j}$ of L14 neurons in situ $(n=3)$, even when neurons were bathed in a $10 \mathrm{~mm}$ octanol suspension for as long as $1 \mathrm{hr}$. Also in culture $(n=4)$, no change was found with octanol (not shown). These

\footnotetext{
Figure 1. Features of electrotonic coupling between cultured Aplysia neurons. $A$, Phase-contrast photograph of the cells recorded from in $B$. $B$, Current $(I= \pm 0.5 \mathrm{nA})$ injected into cell $1\left(V_{1}\right)$ resulted in an electrotonic potential in cell $2\left(V_{2}\right)$. Positive current elicited a train of action potentials in cell 1 , which in turn elicited one-to-one action potential transmission from cell 1 to cell 2 , due to the tight coupling $(k=0.5$, calculated from hyperpolarizing potentials in cell 1 and cell 2). $C$, Voltage recordings of another pair of coupled neurons in culture. Even though the coupling was also strong $(k=0.5)$, the electrotonic psp only reached threshold for spike generation once. This is probably attributable to high threshold in cell 2. Note that the increased action potential width in cell 1 results in an apparent facilitation of the psp in cell 2 (compare psp's early in the record with those at the end of the current pulse). $D$, Phase-contrast picture of the cells recorded from in $E$ and $F$; note that the neurites from these 2 cells are probably intermingled with those of others. $E$, Train of action potentials was generated by positive current injection in cell 1 , which resulted in psp's in cell 2 that were discontinuous in amplitude with spike number. $F$, Train of action potentials in $\mathrm{E}\left(V_{1}\right)$ was spread and superimposed, demonstrating a smooth increase in width and decrease in amplitude. Presumably additional cells in the network coupled to both of these cells reached threshold for spike generation (due to increased spike width in cell 1) and contributed to the apparent coupling potential.
} 

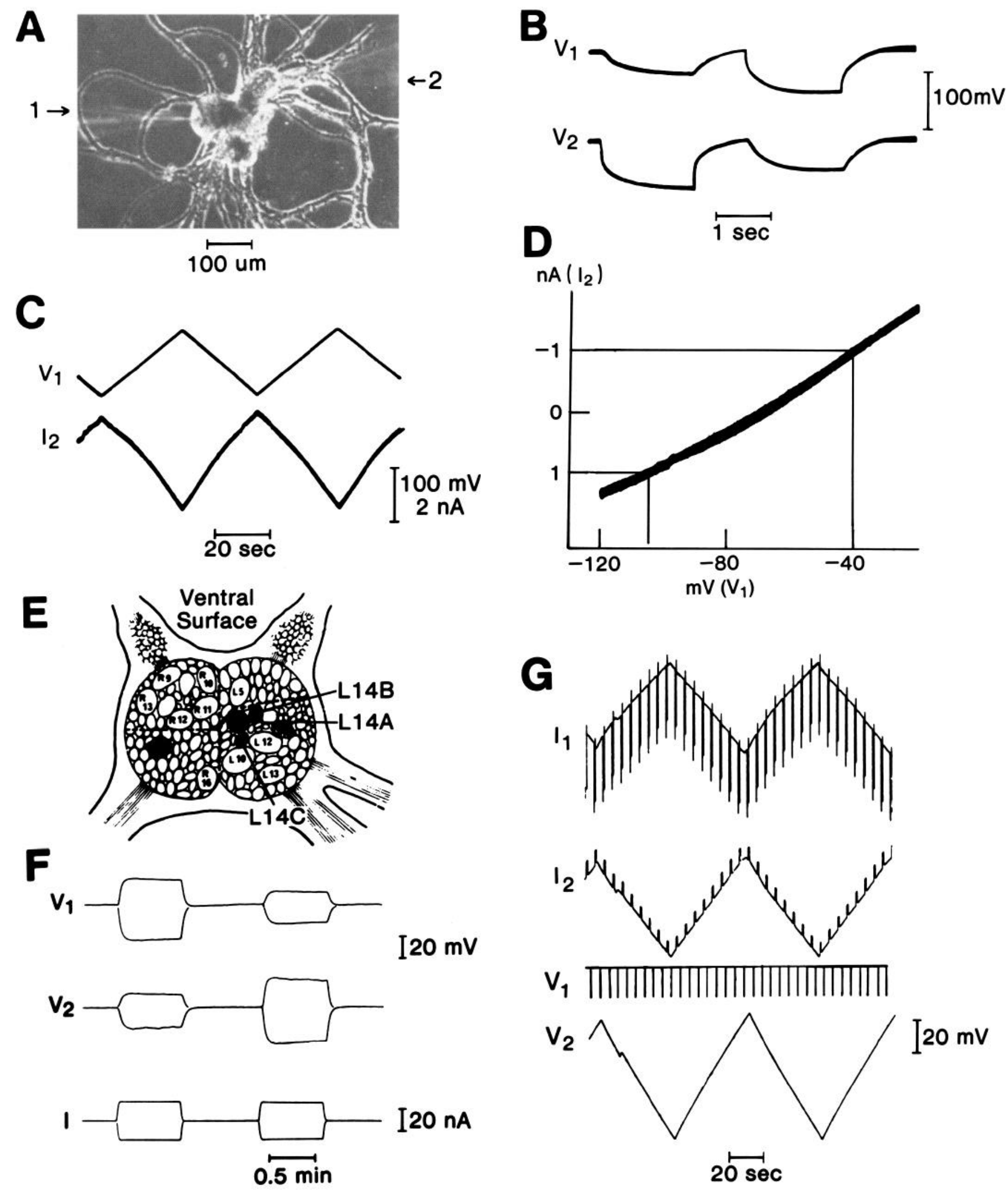

Figure 2. Comparison between calculated and measured junctional conductance $\left(g_{j}\right)$ in culture and in situ. $A$, Phase-contrast photograph of the pair of cultured neurons recorded from in $B-D$. B. Current injected alternately in cell $2\left(I_{2}=-2 \mathrm{nA}\right)$ and cell $1\left(I_{1}=-3 \mathrm{nA}\right)$ resulted in $k_{1 \cdot 2}=$ $V_{2} / V_{1}=0.7$ and $k_{2-1}=V_{1} / V_{2}=0.5$, measured at the end of the pulses. Input resistances: $r_{11}=V_{1} / I_{1}=26 \mathrm{M} \Omega, r_{22}=V_{2} / I_{2}=38 \mathrm{M} \Omega$. $C$, Measurement of $g_{j}$. Both cells were voltage-clamped. $V_{1}$ was swept between -20 and $-120 \mathrm{mV}$ (upper trace), $V_{2}$ was held at $-40 \mathrm{mV}$ and $I_{2}$ was recorded (lower trace), $g_{j}=-d I_{2} / d V_{1}=31 \mathrm{nS}$. $D, I-V$ plot of the measurements in $C$. The slope of $I_{2}$ versus $V_{1}$ is $g_{j}$. Note the approximately linear relationship. $E$, Schematic drawing of the ventral surface of the abdominal ganglion pointing out the L14 neurons (see Waziri, 1969). $F$, Measurement of 


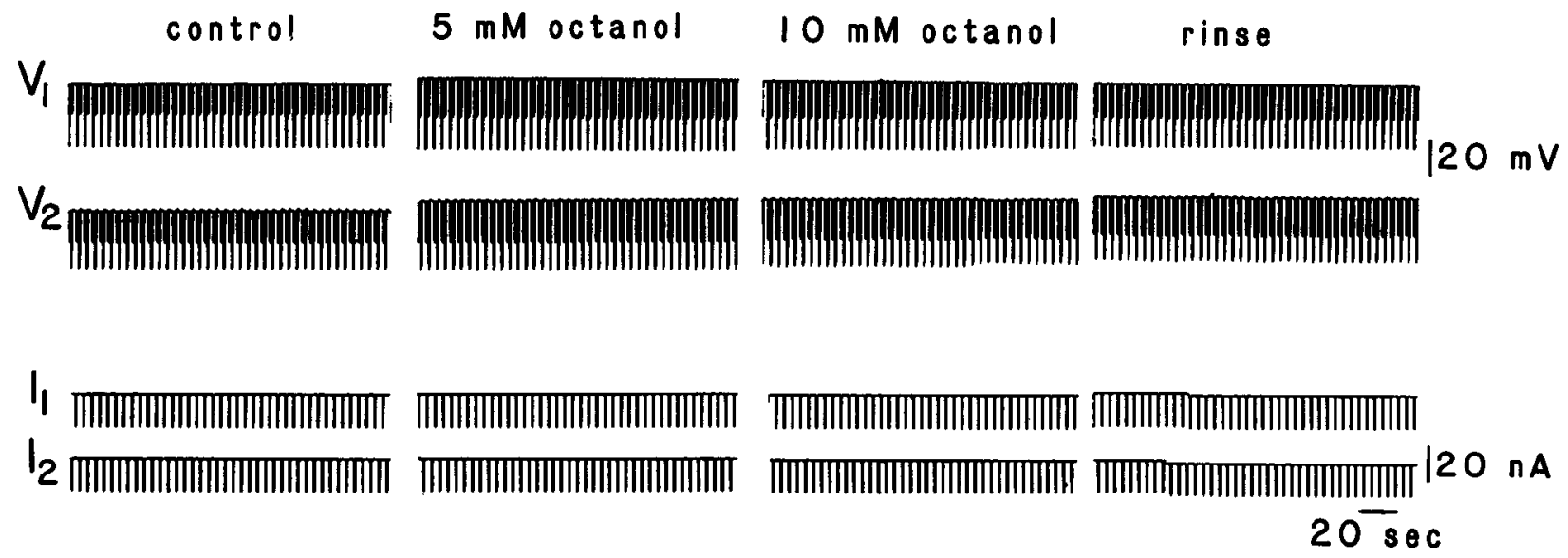

Figure 3. Absence of effect of octanol on electrotonic coupling. First, $5 \mathrm{~mm}$ and then $10 \mathrm{~mm}$ octanol was added to a pair of L14 cells in situ for more than $30 \mathrm{~min}$ each. In this experiment, representative of 7 others, $g_{j}$ was $0.4 \mu \mathrm{S}$ under control conditions and 440, 404 , and $460 \mathrm{nS}$ in cach of the other panels. The coupling coefficient was also relatively constant (about 0.6 ) in each panel.

results are in contrast to many other systems where octanol has been investigated for its potential to block electrotonic transmission (see Spray and Bennett, 1985).

\section{pH dependence of electrotonic synapses}

Application of $\mathrm{CO}_{2}$-equilibrated saline and $\mathrm{NH}_{4} \mathrm{Cl}$ saline to Aplysia neurons in situ acidified and alkalinized the cells, respectively (Fig. 4, $A, B$, lowest traces, intracellular acidity upwards). No change in intracellular $\mathrm{pH}\left(\mathrm{pH}_{\mathrm{i}}\right)$ was observed with perfusion of saline containing impermeant acids or bases buffered to $\mathrm{pH} 5$ (not shown), which is the $\mathrm{pH}$ of the $\mathrm{CO}_{2}$-saturated saline. Figure $4 A$ (lowest trace) shows the typical range over which $\mathrm{pH}_{\mathrm{i}}$ could be varied with these agents. $\mathrm{pH}_{\mathrm{i}}$ changes from 7.1 (at rest) to 7.6 with $\mathrm{NH}_{4} \mathrm{Cl}$ and to 5.9 upon $\mathrm{NH}_{4} \mathrm{Cl}$ withdrawal and exposure to $\mathrm{CO}_{2}$-equilibrated saline. To investigate the influence of $\mathrm{pH}_{\mathrm{i}}$ on electrotonic synapses we used currentand voltage-clamp methods to measure $k$ or $g_{j}$, simultaneously with $\mathrm{pH}_{\mathrm{i}}$.

In situ $k$ changed very little with altered $\mathrm{pH}_{\mathrm{i}}$ (Fig. $4 A$ ). Calculation of $g_{j}$ from equation (6) and the corresponding input resistance valucs $\left(r_{11}\right.$ and $\left.r_{22}\right)$ revcalcd a $50 \%$ reduction of $g_{j}\left(g_{j}\right.$ at $\mathrm{pH}_{\mathrm{i}} 7.6,400 \mathrm{nS}$; at $\left.\mathrm{pH}_{\mathrm{i}} 5.9,200 \mathrm{nS}\right)$, but this effect on the coupling coefficient was offset by a decrease in nonjunctional conductance (at $\mathrm{pH}_{\mathrm{i}} 7.6, g_{n j 2}=0.25 \mu \mathrm{S}$; at $\mathrm{pH}_{\mathrm{i}} 5.9, g_{n j 2}=0.17$ $\mu \mathrm{S})$. Since $k$ will depend on the ratio of $g_{j}$ to $\left(g_{j}+g_{n j}\right)$ (Bennett, 1966), $k$ at $\mathrm{pH}_{\mathrm{i}} 7.6$ was 0.62 and at $\mathrm{pH} 5.9, k$ was 0.54 , a decrease of $13 \%$. The effects of acidification on $g$, measured directly under voltage clamp, is shown for another pair of L14 cells in $s i t u$ in Figure $4 B$. The change of $g_{j}$ with intracellular acidification was from 400 to $200 \mathrm{nS}$, a $50 \%$ reduction, confirming the calculated values for $g_{j}$ in the previous experiment (Fig. $4 A$ ) performed under current clamp.

Figure 4, $C, D$, shows a similar set of experiments as in Figure $4, A, B$, performed on cultured neurons. In culture, $k$ decreased by about $50 \%$ in most cases at low $\mathrm{pH}_{\mathrm{i}}$ (Fig. $4 C$ ), whereas non- junctional conductances were not significantly altered. In $\mathbf{4}$ other experiments in culture, where $k$ was only slightly decreased, nonjunctional conductance decreased as in the in situ cases; this might indicate that nonjunctional conductances of some neurons are differentially sensitive to low $\mathrm{pH}_{\mathrm{j}}$. The decrease in $g_{j}$ in cultured neurons was always more pronounced [ $70-80 \%$ reduction is shown in a current-clamp experiment in Fig. $4 C$; under voltage clamp (Fig. $4 D$ ), $g_{j}$ was reduced by $75 \%$ ] than that obtained with L14 neurons in situ [approximately $50 \%$ in current clamp (Fig. 4C) and voltage clamp (Fig. 4D)].

The relation between $g_{j}$ and $\mathrm{pH}_{\mathrm{i}}$ in cultured neuronal pairs is illustrated in Figure 5 from 3 different voltage-clamp experiments. The relations between $g_{j}$ and $\mathrm{pH}_{\mathrm{i}}$ were shallow and seemed to be somewhat linear; the curves could not be well fit by simple Hill plots (see Spray et al., 1981b). A common feature of all the curves from cultured neurons was a $70-80 \%$ reduction in $g$. The differences among the curves is due to differences in maximal $g_{j}$ values between these neuronal pairs.

Figure $5 C$ presents a summary of 3 different experiments with L14 neurons and the 6 with cultured neurons from Figure 5, $A$, $B$, with $g_{j}$ normalized with respect to the maximal value in each experiment. The L14 curves were also shallow, and the reductions in $G_{j}$ at low $\mathrm{pH}_{i}$ were about $50 \%$. Note that the minimal $G_{j}$ values at the lowest $\mathrm{pH}_{\mathrm{i}}$ values were larger for $\mathrm{L} 14$ neurons than for those obtained from cultured neurons.

\section{Dye injections}

Attempts to detect transfer of LY and the fluorescein derivatives 6-CF and $\mathrm{Cl}_{2} \mathrm{~F}$ between electrotonically coupled neurons in culture and between $\mathrm{L} 14$ neurons in situ $0.5-2 \mathrm{hr}$ after injection are illustrated in Figures 6 and 7. Figure 6 (top panels) shows a pair of cultured neurons whose somata were not directly apposed but were electrotonically coupled (coupling coefficient, $k=0.3$ ), presumably via interconnected neurites. LY diffused rapidly into many of the neurites within the injected cell, but

\footnotetext{
electrotonic coupling between two L14 neurons. $k_{1-2}=k_{2-1}=0.5, r_{11}=r_{22}=1.8 \mathrm{M} \Omega$. $G$, Same two L14 neurons as in $F$ were voltage-clamped. $V_{1}$ was held at $-60 \mathrm{mV}$ with $-20 \mathrm{mV}$ hyperpolarizing command voltage steps, while $V_{2}$ was swept between -10 and $-120 \mathrm{mV}$. The resulting junctional slope conductance was $0.48 \mu \mathrm{S}$. The current deflection in $I_{1}$ resulting from the step pulses in $V_{1}$ remained the same regardless of the potential in $V_{2}$, indicating isopotentiality, and the current deflections in $I_{2}$ were also invariant, suggesting no dependence of $g_{j}$ on inside-outside potential.
} 

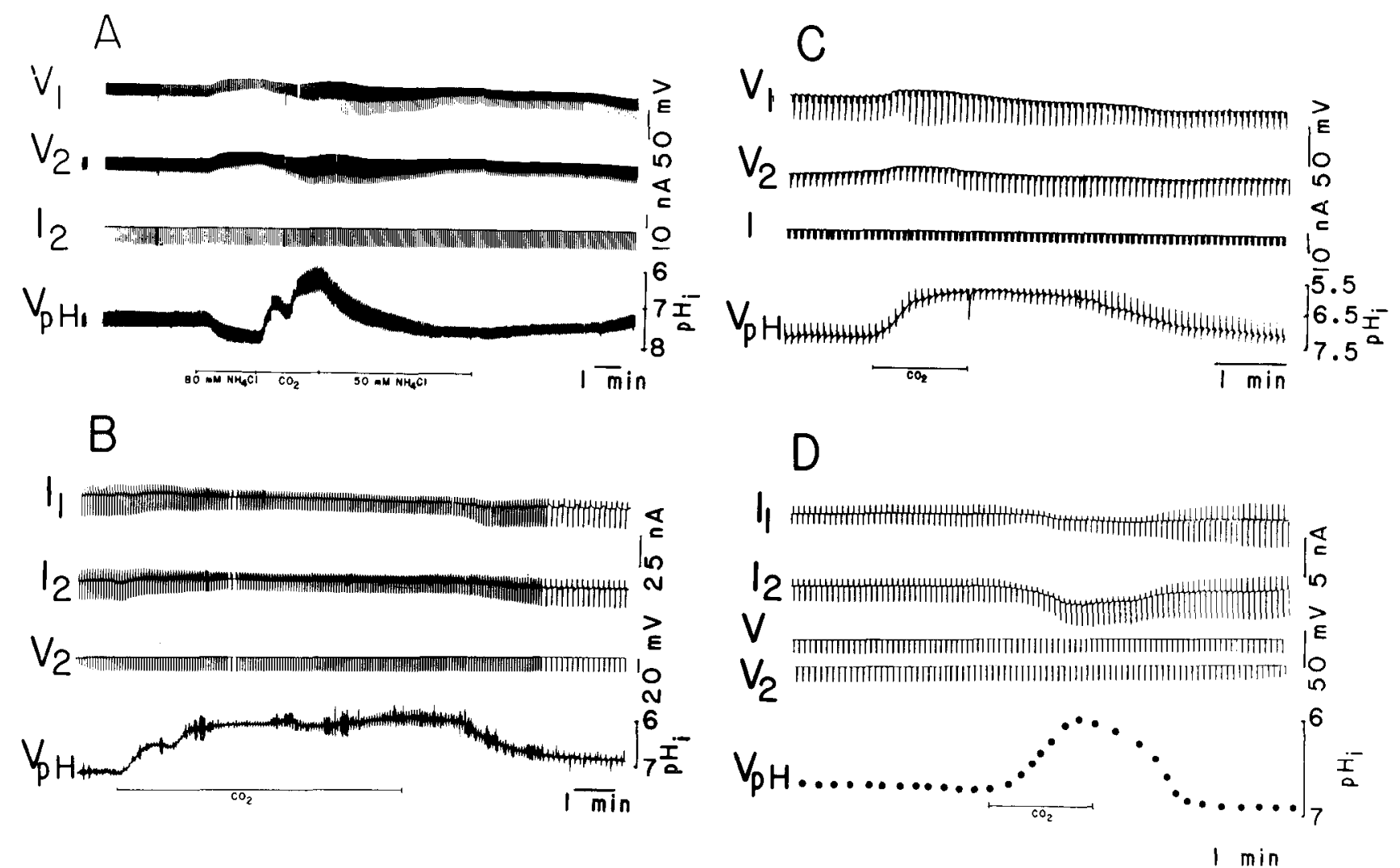

Figure 4. Comparison of $\mathrm{pH}_{\mathrm{i}}$ dependence of $k$ and $g_{j}$ in culture and in situ. In order to measure $\mathrm{pH}_{\mathrm{i}}$, one neuron of a pair was impaled with a $\mathrm{pH}$-sensitive microelectrode. $A$ and $B$, Recordings from 2 pairs of $\mathrm{L} 14$ neurons; $C$ and $D$, recordings from 2 pairs of cultured buccal neurons. $A$ and $C$, Current-clamp records; $B$ and $D$, voltage-clamp records. The up- and downward deflection of the $\mathrm{pH}$ records are transients of the relatively slow response charactcristics of these electrodes. $A$, Cells 1 and 2 receive alternate current injections of $-15 \mathrm{nA}, 0.6 \mathrm{sec}$ duration pulses at $0.2 H_{2}$ (only $I_{2}$ is shown), resulting in voltage deflections in $V_{1}$ and $V_{2}$, respectively, as well as the corresponding coupling potentials $\left(k_{1-2}=k_{2-1}=0.6\right)$. Consecutive addition of $80 \mathrm{mM} \mathrm{NH}_{4} \mathrm{Cl}, \mathrm{CO}_{2}$-saturated saline, and $50 \mathrm{mM} \mathrm{NH}_{4} \mathrm{Cl}$ caused the $\mathrm{pH}_{\mathrm{i}}$ of cell 2 to change between 7.6 and 5.9 . The coupling coefficient was only slightly altered: $k\left(\mathrm{pH}_{\mathrm{i}} 5.9\right)=0.55$. However, the input resistances changed over this $\mathrm{pH}$ range: $r_{11}\left(\mathrm{pH}_{\mathrm{i}} 7.6\right)=2.5$ $\mathrm{M} \Omega, r_{11}\left(\mathrm{pH}_{\mathrm{i}} 5.9\right)=4.5 \mathrm{M} \Omega, r_{22}\left(\mathrm{pH}_{\mathrm{i}} 7.6\right)=2.2 \mathrm{M} \Omega, r_{22}\left(\mathrm{pH}_{\mathrm{i}} 5.9\right)=4 \mathrm{M} \Omega$. The calculated junctional conductances are $g_{j}\left(\mathrm{pH}_{\mathrm{i}} 7.6\right)=400 \mathrm{nS}$ and $g_{j}$ $\left(\mathrm{pH}_{\mathrm{i}} 5.9\right)=200 \mathrm{nS}$. $B$, Cell 1 and 2 were stepped alternately between -60 and $-80 \mathrm{mV}$ command voltage (only $V_{2}$ is shown), and the resulting current changes $I_{1}$ and $I_{2}$ (transjunctional currents are the upward current deflections) were recorded. Upon addition of $\mathrm{CO}_{2}$-saturated saline, the $\mathrm{pH}_{\mathrm{i}}$ changed from 7.3 to 6.0. The corresponding junctional conductances are $g_{j}\left(\mathrm{pH}_{\mathrm{i}} 7.3\right)=400 \mathrm{nS}$ and $g_{j}\left(\mathrm{pH}_{\mathrm{i}} 6.0\right)=200 \mathrm{nS}$. Note that these measured $g_{j}$ values are quite similar to those of the previous pair of L14 neurons $(A)$, where the $g_{i}$ 's were calculated from current-clamp records. $C$, Experiment similar to that shown in $A$ except cultured neurons were impaled and $\mathrm{CO}_{2}$-saturated saline was added to alter $\mathrm{pH}_{\mathrm{i}}$. Transients of the $\mathrm{pH}_{\mathrm{i}}$ trace are truncated at a low $\mathrm{pH}_{\mathrm{i}}$ by the chart recorder. Calculation of junctional and nonjunctional parameters showed that $k$ measured from cell 1 to 2 or cell 2 to 1 decreased from $0.3-0.4$ at $\mathrm{pH} 7.2$ to $0.15-0.2$ at $\mathrm{pH} 5.6$ (50\% change), whereas $g_{j}$ changed from 75 to $20 \mathrm{nS}$ between $\mathrm{pH} 7.2$ and 5.6 (70\% decrease). $D$, Experiment similar to that shown in $B$ but recorded from cultured neurons, with $\mathrm{pH}_{\mathrm{i}}$ decreased from 7 to $6 ; g$ at $\mathrm{pH}_{\mathrm{i}} 7=90 \mathrm{nS}, g_{j}$ at $\mathrm{pH}_{\mathrm{i}} 6=25 \mathrm{nS}$. Note that the relative decrease in $g_{j}$ at low $\mathrm{pH}_{\mathrm{i}}$ is comparable to $g_{j}$ changes obtained in the current-clamp experiment $(C) . \mathrm{pH}_{\mathrm{i}}$ in this case was simultaneously recorded on another chart recorder with a different time scale and is replotted in this figure.

no dye was detected in the electrotonically coupled neighboring cell (arrow in Fig. 6, top) or in other nearby neuronal somata (partially visible at the periphery of the phase photograph). In the cell pair shown in Figure 6 (middle panels), the cell bodies were closely apposed and coupling was strong $(k=0.6)$, but no diffusion of LY into the neighboring cell was detectable up to $2 \mathrm{hr}$ after injection (arrows indicate location of the neighboring cell). In several instances LY appeared to spread into adjacent cells as illustrated in Figure 6, bottom panels, for a pair of closely apposed bag cells. Immediately after the injection a portion of the postjunctional cell directly overlying the injected cell was apparently fluorescent. Closer inspection of the distal margin of this cell (arrows), however, showed no staining, even after 1-2 $\mathrm{hr}$; apparent dye coupling was attributable to refractile material beneath the cells.

LY has a maximum diameter from CPK models of approximately $1.4 \mathrm{~nm}$, whereas the fluorescein derivatives 6-CF and
$\mathrm{Cl}_{2} \mathrm{~F}$ are slightly smaller (maximum diameters of 1.3 and 1.2 $\mathrm{nm}$, respectively). In order to determine whether visualization of dye coupling would improve with the use of a slightly smaller probe, coupled neurons in situ and in culture were injected with 6-CF and $\mathrm{Cl}_{2} \mathrm{~F}$ (not shown). Although coupling was moderately strong $(k=0.2-0.4)$, no dye coupling was observed. Occasional faint staining of cross-ramifying neurites and of adjacent and nonadjacent neurons was attributable to cell autofluorescence.

In summary, we injected 27 pairs of cultured neurons with $\mathrm{LY}, 11$ with $6-\mathrm{CF}$, and 12 with $\mathrm{Cl}_{2} \mathrm{~F}$. All pairs had coupling coefficients $>0.2$. Except for 2 cases, no dye transfer was detected between electrotonically coupled neurons; in 2 cases, transfer with LY was visible only after the cells became depolarized and were no longer excitable.

A similar lack of dye transfer was observed in situ as long as $2 \mathrm{hr}$ after injection of LY $(n=8), 6-\mathrm{CF}(n=3)$, or $\mathrm{Cl}_{2} \mathrm{~F}(n=$ 3 ) into L14 neurons. The coupling coefficients were between 0.4 


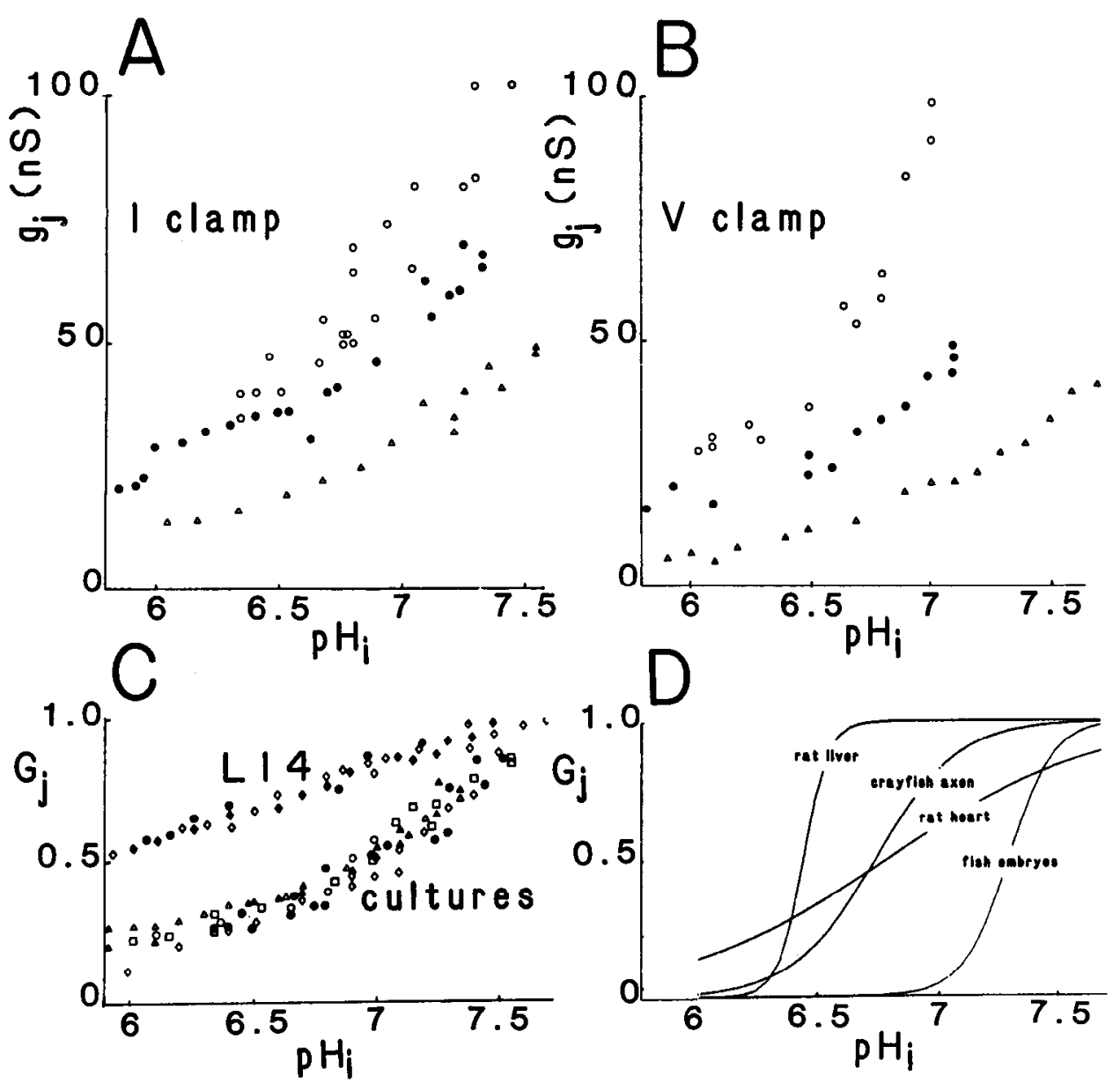

Figure 5. Dependence of $g_{j}$ and normalized $g_{j}\left(G_{j}\right)$ on $\mathrm{pH}_{\mathrm{i}} . A$, Plots of $g_{j}$ calculated from 3 different currentclamp experiments on cultured neurons versus $\mathrm{pH}_{\mathrm{i}} . B$, Plots of $g_{j}$ measured from 3 different voltage-clamp experiments on cultured neurons versus $\mathrm{pH}_{\mathrm{i}}$ (see text). $C$, Cumulative plot of normalized conductance $G_{j}$ (maximal conductance $=1$ ) of 3 different experiments in situ (L14) and the above 6 experiments in culture. Note that the $\mathrm{pH}_{i}-G_{j}$ relations for cultured neurons are steeper than for L14 neurons in situ. D, Comparative $\mathrm{pH}_{\mathrm{i}}$ versus $G_{j}$ plots in different systems (from Spray and Bennett, 1985). Note that the curve for rat heart junctions is closest to Aplysia buccal neurons in culture, but none resembles the behavior of the junctions in L14 neurons in situ. and 0.7. Typical $\mathrm{LY}$ and $\mathrm{Cl}_{2} \mathrm{~F}$ injections into $\mathrm{L} 14$ neurons with confinement of dye to the injected cell are illustrated in Figure 7, top and bottom, respectively. In these experiments the apparent dye diffusion was shown to be artifactual. Figure 7 (top) shows an injected L14 neuron that fluoresced brightly, with an apparent silhouette above it (due to reflection from injected cell), but there was no dye in the L14 neuron to which the injected cell was well coupled (arrow, electrical recording below). Subsequent impalement of the apparently silhouetted cell with a recording electrode showed no detectable electrotonic coupling to the injected cell. Figure 7 illustrates another example of the lack of dye $\left(\mathrm{Cl}_{2} \mathrm{~F}\right)$ transfer between $\mathrm{L} 14$ neurons with the iris on the epi-illuminator closed down to achieve spot excitation and thereby reduce reflection artifact. Spot detection within the neighboring cell revealed no detectable dye transfer.

To estimate the lower limit of dye detectability we injected $\mathrm{LY}$ and $\mathrm{Cl}_{2} \mathrm{~F}$ solutions, serially diluted with extracellular solution, into cultured cells. Fluorescence was detectable in the injected cells using concentrations in the injection electrode as low as $0.1 \%$, which was used in the experiments illustrated in Figures 6, 7. Although the proportionality between the dilution factor and the amount of dye electrophoresed into the cells was not assessed, the concentrations of dye in the neighboring coupled cells $30-120 \mathrm{~min}$ after injection must have been at most $0.1 \%$ of that in the injected cell. We conclude that the dye passage between Aplysia neurons must be considerably restricted compared with other systems in which dye coupling is readily observed.

\section{Permeation of tetraalkylammonium ions between electrotonically coupled neurons}

Because fluorescent dye molecules did not transfer detectably between electrotonically coupled Aplysia neurons we undertook a quantitative study of permeability with the aid of smaller ions. Results of an experiment demonstrating transfer of TEA between L14 neurons in situ is shown in Figure 8. The upper 2 traces show the voltages recorded in the cells $\left(V_{1}, V_{2}\right)$ as a result of current pulses of constant amplitude alternately applied in each cell. The 2 lower traces show the voltages of ion-selective electrodes in the injected cell $\left(\mathrm{TEA}_{2}\right)$ and the coupled recipient cell $\left(\mathrm{TEA}_{1}\right)$. All records are illustrated as short segments (ca. 1$2 \mathrm{~min}$ ) taken at specified times over a duration of $2 \mathrm{hr}$. Representative action potentials in the recipient cell $\left(V_{1}\right)$ are shown as insets for each record segment to illustrate the effects of intracellular TEA on action potential duration. TEA was repeatedly injected into the presynaptic cell (TEA ${ }_{2}$ trace, arrows) in order to achieve a large concentration gradient and sufficient driving force to overcome detection problems in the postsynaptic cell. The threshold for detection is about $0.1 \mathrm{~mm}$ TEA, due to interference from intracellular $\mathrm{K}^{+}$, estimated to be at concentrations of about $0.35-0.4 \mathrm{M}$ in these cells. Transfer to the postsynaptic cell 2 was detected about $10 \mathrm{~min}$ after the third injection and continued until the end of the experiment $(2 \mathrm{hr})$, at which time the measured TEA concentration was about 20 $\mathrm{mM}$ in the postsynaptic cell and $300 \mathrm{~mm}$ in the injected cell. Transfer of TEA to the postsynaptic cell was also evident be- 

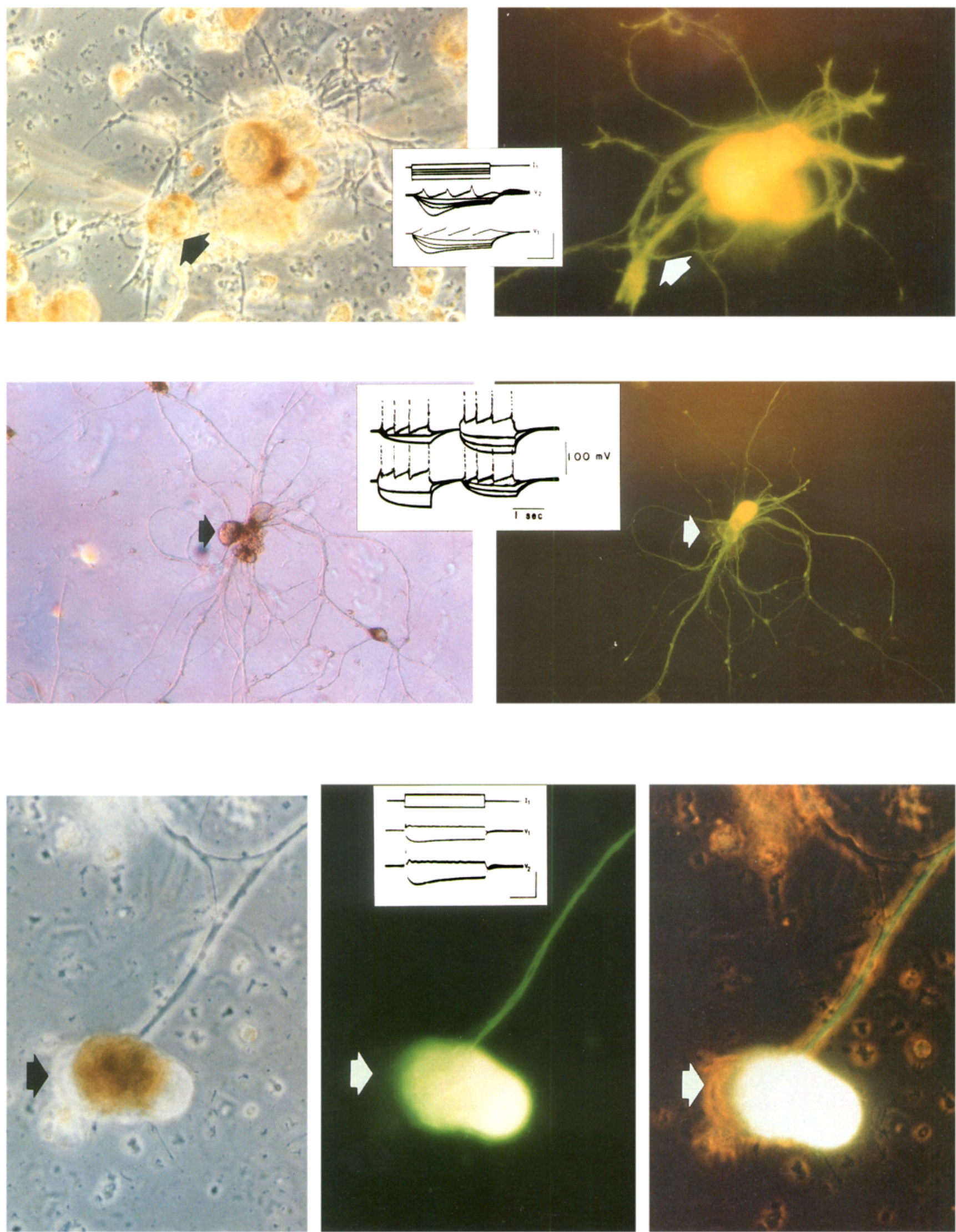

Figure 6. Dye injection into cultured neurons. Top panels, Separate cells with interconnecting neurites: At left is a phase-contrast picture showing 2 impaled neurons; the corresponding epifluorescence picture (right) shows that LY stained most neurites, but dye did not detectably transfer to the electrotonically coupled cell (arrow; $k=0.3$ ). Middle panels, Closely apposed cells. At left a Nomarski picture of apposed neurons is shown. 

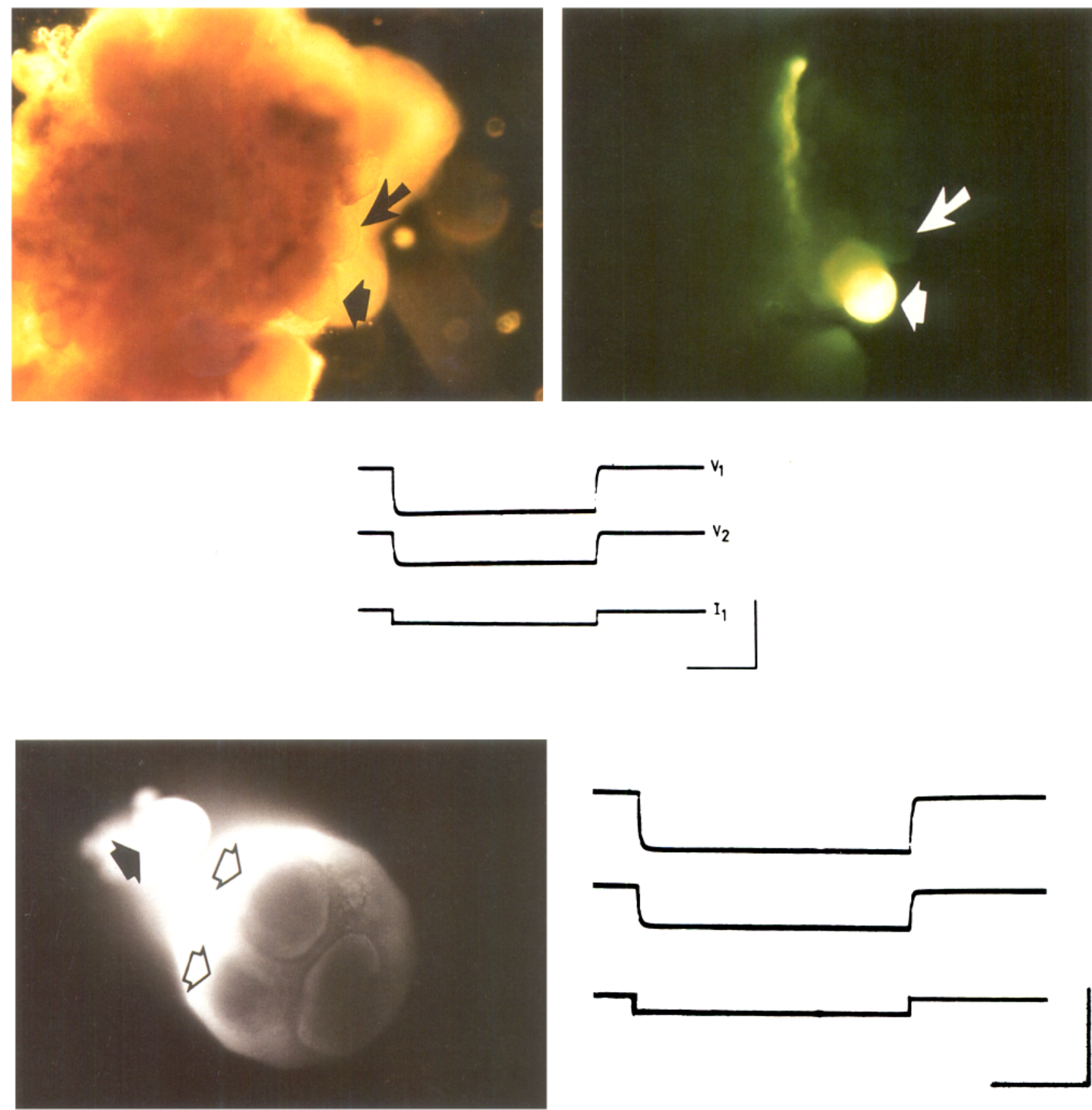

Figure 7. Injections of fluorescein derivatives into cultured neurons. Left panels, Dichlorofluorescein injection into 1 of 2 coupled cells $(k=0.3)$. No dye transfer was detected to the uninjected cell (arrow). Right-hand panels, 6-CF injection into 1 of 2 electrotonically coupled neurons $(k=$ $0.2-0.4$ ). No fluorescence was detected in the other cell except for the neurites as in Figure 1 (bottom). Calibrations: $50 \mathrm{mV}, 0.6 \mathrm{sec}, \mathrm{current} 2 \mu \mathrm{A}$.

cause of broadening of the action potential induced by pharmacological blockade of delayed rectifier $\mathrm{K}^{+}$current (cf. Stanfield, 1983). Only after 50-70 min was an increase in the duration of the action potential evident in the postsynaptic cell (trace $d$ ); the TEA concentration was more than $1 \mathrm{~mm}$. After sufficient transfer of TEA, durations of action potentials evoked directly in the postsynaptic cell were consistently longer than those evoked by transsynaptic stimulation (cf. traces $d$ and $f$,

LY was injected into one cell depicted by the fluorescence photo at right. Note that many neurites originating from the cluster are fluorescent, but cell 1 to which cell 2 is electrotonically coupled ( $k=0.6$, not shown) is not dye-coupled (arrow). Bottom panels, Apparent dye coupling. At left is a phase-contrast photograph of 2 closely apposed bag cells, right cell having been injected with LY. The arrow points to the left margin of the electrotonically coupled cell $(k=0.5)$. Photograph in the center is of the same field with epifluorescence; at right, the same field is shown with both transmitted light and epifluorescence. Although part of the left cell appears fluorescent, dye coupling must be ruled out because the left side of the cell at the left is unstained. The fluorescent halo under the left cell was probably due to neurites originating from the dye-injected cell ramifying under the other. No dye coupling was observed in these cells as long as 30-120 min after LY injection. Calibrations: Top: $V_{1}, 100 \mathrm{mV} ; V_{2}, 20 \mathrm{mV}$; $0.2 \mathrm{sec}$; currents, $\pm 1,-2,-3 \mu \mathrm{A}$; middle: $V_{1}, V_{2}, 100 \mathrm{mV} ; 1 \mathrm{sec}$ currents $\pm 1,-2,-3 \mu \mathrm{A}: C: V_{1}, 100 \mathrm{mV} ; V_{2}, 40 \mathrm{mV} ; 0.1 \mathrm{sec} ;$ currents $\pm 2 \mu \mathrm{A}$. 

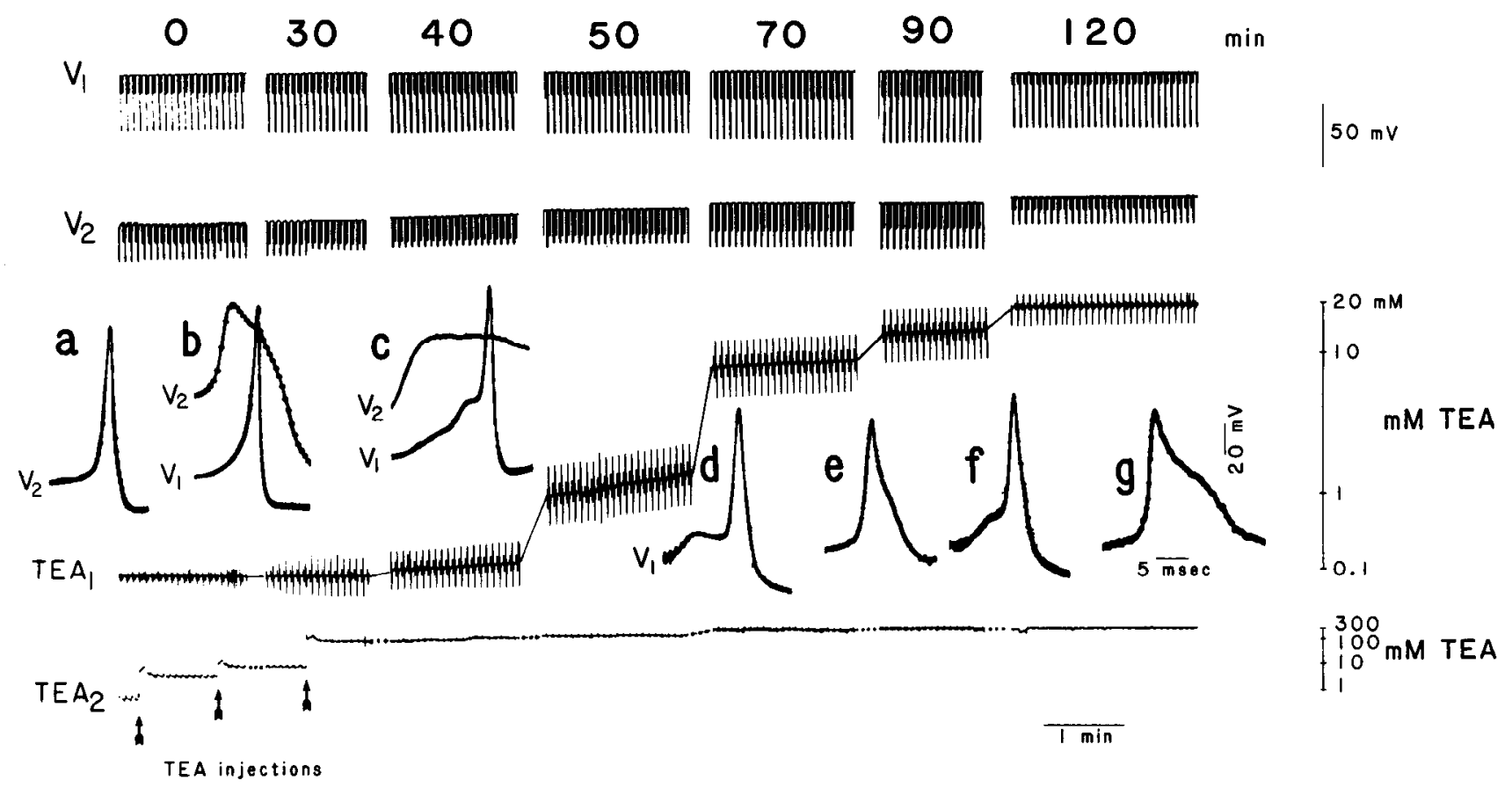

Figure 8. TEA transfer between two L14 neurons in situ. Current pulses of $-15 \mathrm{nA}$ (traces not shown) were alternately injected into cell 1 ( $V_{1}$ ) and cell $2\left(V_{2}\right)$ to monitor junctional conductance (which changed only toward the end of the experiment). $V_{1}$ electrode was filled with $0.5 \mathrm{M} \mathrm{KCl}$ and $V_{2}$ with 1 м TEA. Three TEA injections (arrows) into cell 2 resulted in an intracellular TEA concentration of about 100 mm. Ten minutes after the TEA injections in cell 1, transfer of TEA to cell 2 became detectable and progressively increased to $20 \mathrm{~mm}$ after $2 \mathrm{hr}$. Inset, Fast sweep voltage traces show the shape of the action potential at approximately the times indicated above $V_{1}$. Note the action potential width increase in cell 2 after the first 2 injections and an even greater increase after the third $\left(V_{2}\right)$. The action potential of ccll 1 has becn elicited transjunctionally by stimulating cell 2 in the traces $b-d$ and $f$ and by direct stimulation in the traces $e$ and $g$. The width was increased only when the TEA concentration of cell 1 exceeded $1 \mathrm{~mm}$. Note that the width increase was more pronounced when cell 1 was directly stimulated (traces $e$ and $g$ compared with trace $f$ ). Trace $a$ is an action potential elicited in cell 2 (with direct stimulation) before TEA injection. TEA concentrations were calculated as described in Materials and Methods. Note the short latency in trace $b(<5 \mathrm{msec})$, indicating a short distance from cell body to the junction.

which are evoked transsynaptically, with $e$ and $g$, which are evoked by direct stimulation). This result is opposite that for action of TEA along the expected concentration gradient from axon to soma of the postsynaptic cell and may suggest that TEAsensitive channels are differentially distributed between the axon and the soma. The threshold for TEA action was at least $1 \mathrm{mM}$ and the variability in spike width is considerable. Estimation of TEA concentration from action potential duration was therefore much less reliable than measuring TEA concentration directly with $\mathrm{K}^{+}$-sensitive electrodes.

Figure $9 A$ shows the time course of the rise in TEA concentration in the recipient cell from the in situ experiment illustrated in Figure 8. The inset shows the calibration measurement of the ion-selective electrodes prior to the experiment (calibrations did not change appreciably after the experiment). Figure $9 B$ shows the result of a similar experiment with TMA injected into one cell of a pair of L14 neurons. The maximal TMA concentration obtained in the postsynaptic cell after $50 \mathrm{~min}$ was about $20 \mathrm{~mm}$. (The limit of detection in the recipient cell was also $0.1 \mathrm{~mm}$ TMA.) Electrode calibration appears in the inset (slope, $60 \mathrm{mV} /$ 10-fold change in TMA). Figure 10 illustrates examples of tetraalkylammonium ion transfer experiments between neurons in culture. For TEA (Fig. 10A) and TMA (Fig. 10B), injection resulted in large transfers to recipient cells within $60 \mathrm{~min}$.

A summary of tetraalkylammonium ion transfer data for neurons in culture and in situ is presented in Table 1. Transjunctional flux $(J)$ and permeability $(P)$ were calculated from records such as those shown in Figures 9 and 10 using Eqs. 1 and 3 (see
Materials and Methods). Junctional conductance $\left(g_{j}\right)$, which was measured simultaneously, is included for comparison.

Junctional permeability $\left(P_{j}\right)$ values for either TMA or TEA and corresponding $g_{j}$ 's obtained in situ are larger than for cells in culture. Several pairs of weakly coupled neurons in culture exhibited little or no TMA transfer (Table 2). The low value of $g_{j}$ in these cases may have reduced the flux of TMA to below detection threshold.

\section{Discussion}

We show here that nonlinearities in electrotonic transmission in cultured Aplysia neurons are attributable to properties of the nonjunctional membrane as described previously in Aplysia (Carew and Kandel, 1976; Rayport and Kandel, 1980). The adequacy of voltage-clamp techniques for studies of synaptic events in Aplysia has been demonstrated for situations in which the synaptic site is located near the isopotential region of the voltage-clamped cell (Shapiro et al., 1980). L14 neurons are located next to each other in the ganglion (Fig. $2 E$ ), and the strong coupling (Fig. $2 F$ ) suggests that the synapse lies within short electrotonic distance from the somata. In culture, cell pairs chosen for voltage clamp were close together (e.g., Fig. $2 A$ ); since cultured neurons can couple well without visible neurites (Bodmer, 1983), we conclude that the electronic synapses in culture were located close to the soma and were therefore controllable by the voltage-clamp circuits.

We found that there was no appreciable voltage dependence of the electrotonic synapses themselves. This is the case for most 

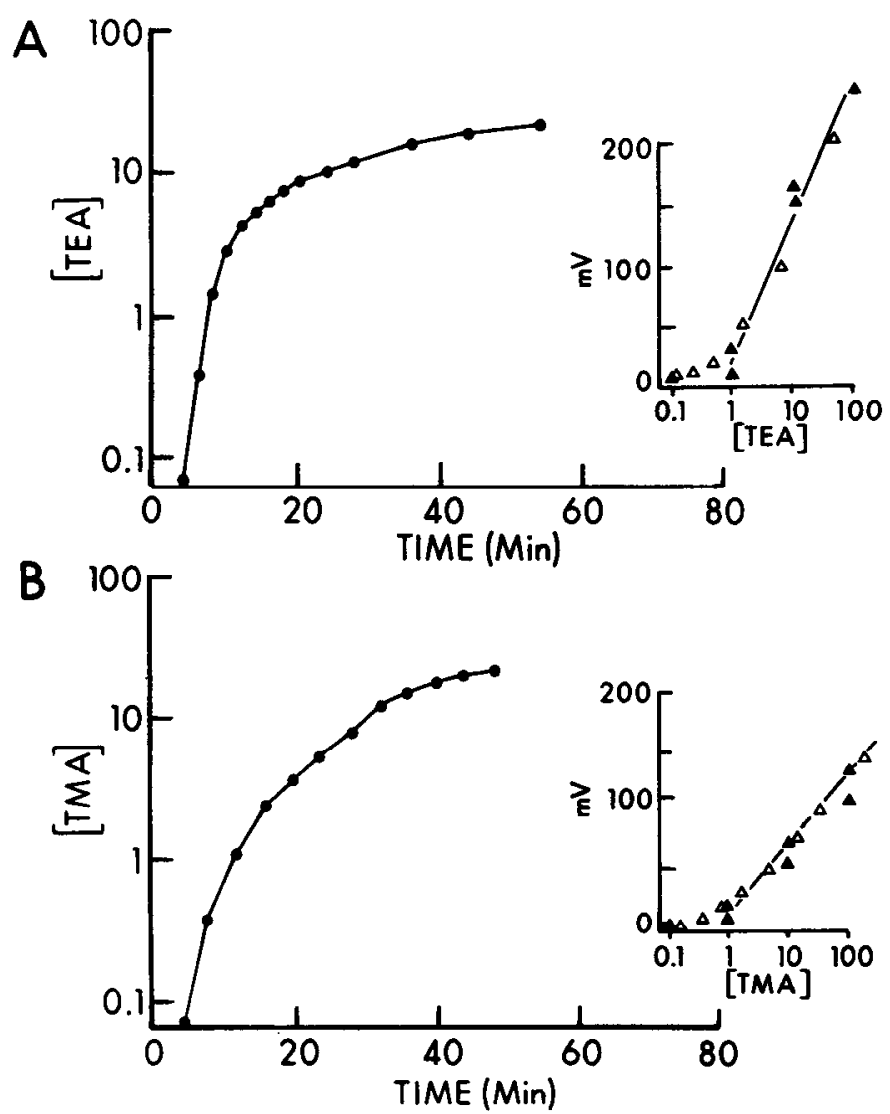

Figure 9. TEA $(A)$ and TMA $(B)$ transfer between L14 neurons. $A$, Time course of TEA transfer (data frum Fig. 8) beginning after the third TEA injection (time zero). TEA concentrations measured with $\mathrm{K}^{+}$-sensitive electrodes were calculated from equations (4) and (6) (Materials and Methods) using the calibration curve (inset), obtained immediately after the experiment. Final TEA concentration in injected cell 2 and recipient cell 1 were $0.3 \mathrm{M}$ and $20 \mathrm{~mm}$, respectively. Intracellular $\mathrm{K}^{+}$ concentrations were estimated to be $0.3 \mathrm{M}$. B. TMA transfer between two L14 neurons. Time course of transfer in an experiment similar to that shown in $A$ but using TMA as a probe. Inset, calibration curve for both $\mathrm{K}^{+}$-sensitive electrodes obtained immediately after the experiment. Estimated intracellular $\mathrm{K}^{+}$concentration was $0.3 \mathrm{~m}$. Final TMA concentrations: recipient cell, $20 \mathrm{~mm}$; injected cell, $0.25 \mathrm{M}$.

gap junctions studied in detail so far (cf. Spray and Bennett, 1985); exceptions include a few cases of rectifying electrotonic synapscs (Furshpan and Potter, 1959; Auerbach and Bennett, 1969; Nicholls and Purves, 1972; Margiotta and Walcott, 1983)

Table 1. Transfer of TMA and TEA between coupled Aplysia neurons

\begin{tabular}{llll} 
Experiment & $\begin{array}{l}\text { Flux } \\
(\mathrm{mol} / \mathrm{sec})\end{array}$ & $\begin{array}{l}\text { Permeability } \\
\left(\mathrm{cm}^{3} / \mathrm{sec}\right)\end{array}$ & $\begin{array}{l}g_{j} \\
(\mu \mathrm{S})\end{array}$ \\
\hline TMA & & & \\
$\quad$ L14) & $3-7 \times 10^{-14}$ & $1-3 \times 10^{-10}$ & 0.2 \\
(Culture) & $0.5-1.2 \times 10^{-15}$ & $1.3-3 \times 10^{-12}$ & 0.017 \\
& $1-2 \times 10^{-16}$ & $2-4 \times 10^{-13}$ & 0.021 \\
TEA & & & \\
(L14) & $0.7-2 \times 10^{-14}$ & $2-8 \times 10^{-11}$ & 0.22 \\
& $2.4 \times 10^{-14}$ & $6-12 \times 10^{-11}$ & 0.25 \\
(Culture) & $0.3-1 \times 10^{-16}$ & $2-5 \times 10^{-13}$ & 0.033 \\
\hline
\end{tabular}
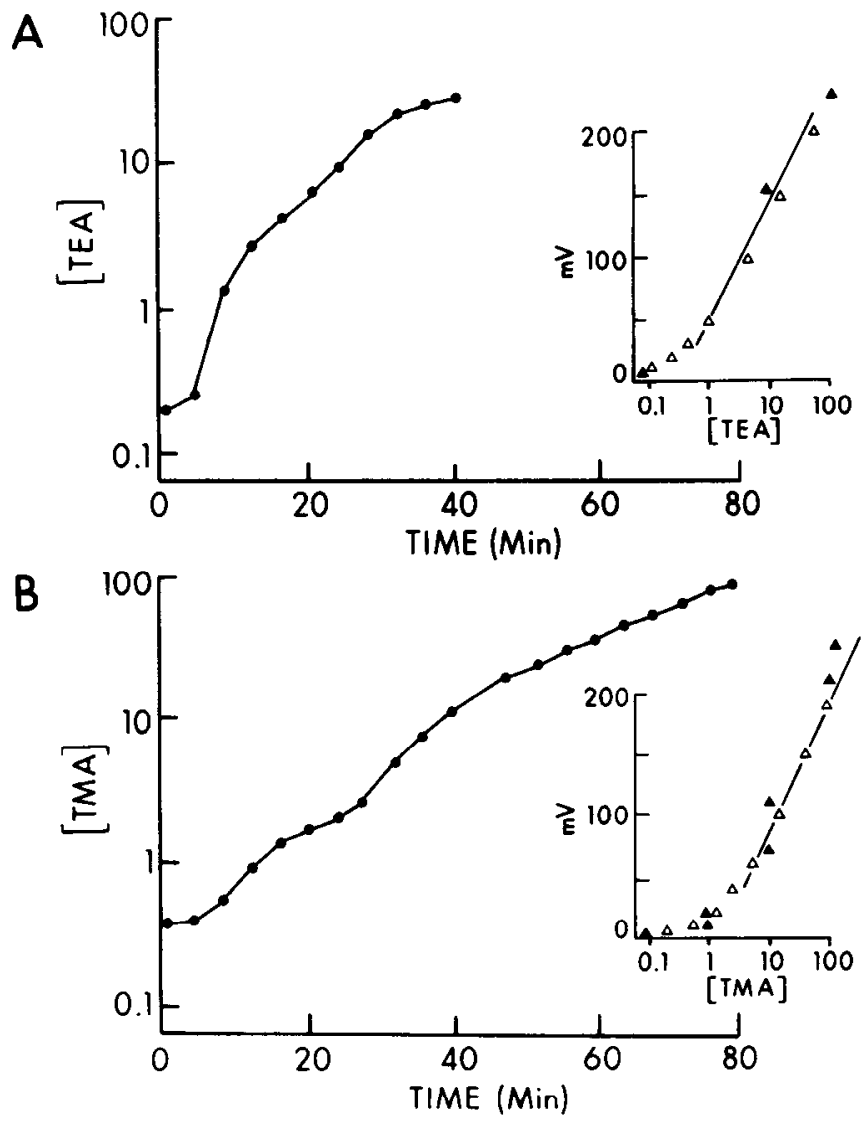

Figure 10. TEA $(A)$ and TMA $(B)$ transfer between cultured neurons. Experiments similar to those shown in Figure 10 but with cultured neurons. $A$, Final TEA concentration in the recipient cell was $3 \mathrm{~mm}$. $B$, Final TMA concentration in the recipient cell was $90 \mathrm{~mm}$; final TMA concentration in the injected cell, $0.4 \mathrm{M}$. TEA and TMA concentrations were calculated from equations (1) and (3) (Materials and Methods). Insets, Calibration curves obtained as in Figure 9.

and all early embryos thus far examined (Spray et al., 1985). Considering their presumed function in impulse transmission, the voltage independence of Aplysia electrotonic synapses has apparent value because $\mathrm{L} 14$ neurons mediate the inking behavior in Aplysia, which requires fast, synchronous transmission (Kandel, 1976).

The junctional conductance $\left(g_{j}\right)$ of all the coupled cell pairs we investigated showed a significant dependence on cytoplasmic acidification. The relation between $\mathrm{pH}_{i}$ and $g_{j}$ in all cases exhibited a shallow slope and large residual $g_{j}$ at low $\mathrm{pH}_{\mathrm{i}}(\mathrm{Fig}$.

\begin{tabular}{llll}
\hline Table 2. & TMA transfer, $\boldsymbol{k}$ and $\boldsymbol{g}_{\boldsymbol{j}}$ between cultured neurons \\
& & $\begin{array}{l}\boldsymbol{g}_{j} \\
\text { (nS) }\end{array}$ & $\begin{array}{l}\text { TMA } \\
(\mathrm{mM})^{a}\end{array}$ \\
No. & $k$ (mean) & 17 & 1.5 \\
1 & 0.6 & 21 & 2.2 \\
2 & 0.4 & 18 & $0.1-0.5$ \\
3 & 0.3 & 11 & $0.1-0.5$ \\
4 & 0.15 & 10 & $0^{b}$ \\
5 & 0.15 & 10 & $0.1-0.5$ \\
6 & 0.1 & 10 &
\end{tabular}

${ }^{a}$ Concentration of TMA in the recipient cell 20 min after injection.

${ }^{b}$ No transfer detected up to $40 \mathrm{~min}$ after injection. 
5C). Neurons in situ showed a reduced $\mathrm{pH}$ sensitivity. Possible explanations include $\mathrm{pH}$ sensitivity of the series resistance (see below) and failure of the somatic $\mathrm{pH}_{\mathrm{i}}$ recording to measure $\mathrm{pH}_{\mathrm{i}}$ at the site of coupling. The $g_{j}-\mathrm{pH}_{\mathrm{i}}$ relations could not be fit well to simple Hill plots, implying that $g_{j}$ is not a simple function of $\mathrm{pH}_{\mathrm{i}}$. Interference of $\mathrm{pH}$ dependence of the nonjunctional membrane can only partially account for these results since extreme decreases in nonjunctional conductance would be required to compensate for a substantial decrease in $g_{j}$. (Since the equivalent resistances are in series, reducing $g_{j}$ by $90 \%$ would produce an apparent reduction of $50 \%$ only if the shunting along the coupling pathway were reduced 5-fold.) For effects of $\mathrm{pH}_{\mathrm{i}}$ on coupling coefficient, however, nonjunctional membrane properties are likely to play a major role. With shunting resistances $\left(r_{s}\right)$ symmetrically interposed between soma and site of electrotonic connection, the coupling coefficient, $k$, is determined by $k=r_{2} /$ $\left(r_{2}+2 r_{\mathrm{s}}+r_{j}\right)$, where $r_{2}$ is the nonjunctional resistance of the cell in which coupling is measured and $r_{s}$ is the parallel sum of shunts to extracellular medium along the coupling pathway (which presumably have a pII dependence similar to that of somatic nonjunctional membrane). Consider the case in which $k=0.5$ and $r_{j}=2 r_{s}$. If $r_{2}$ at $\mathrm{pH} 6$ is twice that at pH 7 and $r_{s}$ has the same $\mathrm{pH}$ dependence, reducing $r_{j}$ by $70 \%$ would decrease $k$ by less than 0.01 (see equation 2). Such a contribution of nonjunctional membranes to promoting conduction under reduced $\mathrm{pH}_{\mathrm{i}}$ has been pointed out previously in studies on crayfish septate axon (Giaume et al., 1980; Campos de Carvalho et al., 1984 ) and should be kept in mind when $k$ is measured without assessing $g$, directly.

Most systems seem to have $\mathrm{pH}_{\mathrm{i}}$-dependent gap junctions (cf. Spray and Bennett, 1985); and those studied in detail all close sigmoidally with various $\mathrm{p} K$ 's (see also Fig. $5 D$ ). Thus, the gap junctions of L14 cells in situ and buccal neurons in culture have a quantitatively different regulation by $\mathrm{pH}_{\mathrm{i}}$ compared with any other system known, and possibly also a qualitatively different pharmacology as indicated by their insensitivity to octanol.

Recently, Connors et al. (1984) reported that dye coupling between pyramidal neurons in neocortical slices was relatively insensitive to $\mathrm{CO}_{2}$, while dye passage between astrocytes was blocked by $\mathrm{CO}_{2}$ treatment. Previously, Schuetze and Goodenough (1982) found decreased $\mathrm{CO}_{2}$ sensitivity of dye transfer in later developmental stages of a non-neuronal system (chick lens). Although the extent to which $g_{j}$ was affected and the minimal $\mathrm{pH}_{\mathrm{i}}$ values reached in these experiments are unknown, these findings suggest that there might be classes of gap junctions less sensitive to $\mathrm{pH}_{\mathrm{i}}$. The possibility that there are several different gap junctional proteins is supported by many reports (e.g., Nicholson et al., 1983; Revel et al., 1985) where polypeptide maps and partial amino acid sequences of gap junctions from different tissues in a single species were substantially nonhomologous. Using a polyclonal antibody to rat liver gap junctions (Hertzberg and Skibbens, 1984), gap junctional protein was not detected in immunoblots of $A$ plysia ganglia (Hertzberg and Spray, 1985), again supporting the possibility of gap junction heterogeneity.

Injection of the fluorescent dyes $\mathrm{LY}, 6-\mathrm{CF}$, and $\mathrm{Cl}_{2} \mathrm{~F}$ into $\mathrm{L} 14$ neurons in situ as well as into cultured neurons resulted in no detectable spread to electrotonically coupled neighboring cells (Figs. 6, 7). The lack of dye coupling is in contrast to many other systems where one criterion used to assess coupling via gap junctions is rapid dye spread to neighboring cells (Spray and Bennett, 1985). There are, however, several systems where electrotonic coupling is present, whereas dye coupling is not (Muller, 1981; Warner and Lawrence, 1982), including neurons of other molluscs (Audesirk et al., 1982; Murphy et al., 1983). One possible explanation for the absence of dye coupling is that the size of the gap junction channel is smaller in some tissues of some species, at some developmental stages or by partial closure induced by a change in functional state. Apparent diversity of channel size has been reported where gap junctions between salivary gland cells in arthropods were found to be more permeable than gap junctions connecting mammalian cells (Schwartzmann et al., 1981). Nevertheless, initial suggestions that size of the gap junction channel might be developmentally regulated (see Warner and Lawrence, 1982) have not been substantiated by subsequent studies (see Bennett et al., 1978; Safranyos et al., 1986), and constrictive closure of the gap junction channel by physiological stimuli (see Loewenstein, 1981) has not been supported in quantitative studies on voltage-dependent gating in arthropod salivary gland and amphibian embryonic cells (Zimmerman and Rose, 1985; Verselis et al., 1986b).

It is clear that the permeabilities of the fluorescent dye molecules used in the present study were considerably less than to the small ions that carry current between coupled cells. Two molecules (TMA and TEA), which are considerably smaller in size than the dyes, were permeable between electrotonically coupled neighboring cells both in situ and in culture. In some instances, transfer was quite rapid when cells were well coupled (Table 1). Permeabilities were often difficult to measure between cells in which $g_{j}$ was low $(<20 \mathrm{nS})$ (see Table 2$)$. Factors contributing to the difficulty in measuring low permeabilities to TEA and TMA could include slight nonjunctional permeability to the probes causing leakage out of the cells and interference from $\mathrm{K}^{+}$leaking into the cells from the microelectrodes.

The high coupling coefficients we report here were due to high input resistances of the cells relative to the junctional membrane and obscure the rather low values of junctional conductance we gencrally cncountered (10-100 nS). The fluxes of the tetraalkylammonium compounds measured in Aplysia neurons were slightly less than those found in fish and amphibian embryos when scaled for $g_{j}$ (Verselis et al., 1986a, b). It follows that in electrotonic synapses of Aplysia, the ratio of permeability to conductance may be somewhat lower than for other tissues. Taking into consideration the geometry of the synapse, we cannot conclude unambiguously that the gap junction channels in Aplysia are smaller. Extrapolating the low permeabilities of the smaller tetraalkylammonium ions to the dye molecules would put dye permeabilities at very low values. This, together with the high detection threshold caused by somatic autofluorescence in the Aplysia ganglion, could obscure a low junctional dye permeability.

Aplysia neuronal gap junctions combine a characteristic set of responses to physiological stimuli (compare the present report with the summary in Spray et al., 1985) with a definable rangc of permeabilities to tracer molecules. Frictional models for diffusion through restricted pores predict that permeability decreases rapidly as molecules approach the diameter of the channels (Renkin, 1955). The low conductance of the junctional membrane in these cells and the finding that ratios of $P_{j}$ to $g_{j}$ in Aplysia are somewhat lower than in other preparations raises the possibility that the apparent junctional impermeability to larger molecules may represent junctional channels of distinctly smaller aperture or with charge selectivity (see Brink, 1985). Unambiguous resolution of this issue, however, will require 
quantitative studies of junctional permeability to nonreactive tracer molecules of a greater size and charge range, or singlechannel measurements, where unitary events can be viewed directly.

\section{References}

Adams, W. B., I. Parnas, and I. B. Levitan (1980) Mechanism of longlasting synaptic inhibition in Aplysia neuron R15. J. Neurophysiol. 44: 1148-1160.

Atkinson, M. M., and J. D. Sheridan (1985) Reduced junctional permeability in cells transformed by different viral oncogenes. In Gap Junctions, M. V. L. Bennett and D. C. Spray, eds., pp. 205-213, Cold Spring Harbor Laboratories, NY.

Audesirk, G., T. Audesirk, and P. Bowsher (1982) Variability and frequent failure of Lucifer Yellow to pass between two electrically coupled neurons in Lymnaea stagnalis. J. Neurobiol. 13: 369-375.

Auerbach, $\Lambda$. $\Lambda$., and M. V. L. Bennett (1969) $\Lambda$ rectifying synapse in the central nervous system of a vertebrate. J. Gen. Physiol. 53: 211-237.

Bennett, M. V. L. (1966) Physiology of electrotonic junctions. Ann. NY Acad. Sci. 137: 509-539.

Bennett, M. V. L., and D. C. Spray, eds. (1985) Gap Junctions, Cold Spring Harbor Press, NY.

Bennett, M. V. L., M. E. Spira, and D. C. Spray (1978) Permeability of gap junctions between embryonic cells. A reevaluation. Devl. Biol. 65: 114-125.

Bodmer, R. (1983) Properties of Aplysia neurons in primary cell culture. Ph.D. dissertation, I Iniversity of Basel, Switzerland.

Bodmer, R., and D. C. Spray (1985) Permeability and electrophysiological properties of electrotonic synapses between Aplysia neurons in situ and in culture. Biophys. J. 47: 504a.

Bodmer, R., D. Dagan, and I. B. Levitan (1984) Chemical and electrotonic connections between Aplysia neurons in primary culture. $\mathrm{J}$. Neurosci. 4: 228-233.

Brenowitz, G. L., W. F. Collins, and S. D. Erulkar (1983) Dye and electrical coupling between frog motoneurons. Brain Res. 274: $371-$ 375.

Brink, P. R. (1985) The effects of deuterium oxide on junctional membrane permeability and conductance. In Gap Junctions, M. V. L. Bennett and D. C. Spray, eds., pp. 123-138, Cold Spring Harbor Laboratories, NY.

Campos de Carvalho, A. C., D. C. Spray, and M. V. L. Bennett (1984) $\mathrm{pH}$ dependence of transmission at electrotonic synapses of the crayfish septate axon. Brain Res. 321: 276-286.

Carew, T. J., and E. R. Kandel (1976) Two functional effects of decreased conductance EPSPs: Synaptic augmentation and increased electrotonic coupling. Science 192: 150-153.

Connors, B. W., L. S. Benardo, and D. A. Prince (1984) Carbon dioxide sensitivity of dye coupling among glia and neurons of the neocortex. J. Neurosci. 4: 1324-1330.

Dagan, D., and I. B. Levitan (1981) Isolated identified Aplysia neurons in cell culture. J. Neurosci. $1: 736-740$.

Fraser, E., and J. Bryant (1985) Patterns of dye coupling in the imaginal wing disk of Drosophila melanogaster. Nature 317: 533-536.

Frazier, W., E. Kandel, I. Kupfermann, R. Waziri, and R. Coggeshall (1967) Morphological and functional properties of identified neurons in the abdominal ganglion of Aplysia. J. Neurophysiol. 30: 12881351.

Furshpan, E. J., and D. D. Potter (1959) Transmission at the giant motor synapses of the crayfish. J. Physiol. (Lond.) 145: 289-325.

Gardner, D. (1977) Interconnections of identified multiaction interneurons in buccal ganglia of Aplysia. J. Neurophysiol. 40: 349-361.

Giaume, C., M. E. Spira, and H. Korn (1980) Uncoupling of invertebrate electrotonic synapses by carbon dioxide. Neurosci. Lett. 17: 197-199.

Gillette, R., and B. Pomeranz (1975) Ultrastructural correlates of interneuronal function in the abdominal ganglion of Aplysia californica. J. Neurobiol. 6: 463-474.

Goldman, D. E. (1943) Potential, impedance, and rectification in membranes. J. Gen. Physiol. 27: 37-60.

Hall, D. H., D. C. Spray, and M. V. L. Bennett (1983) Gap junctions and septate like junctions between neurons of the opisthobranch mollusc, Navanax inermis. J. Neurocytol. 12: 831-846.

Hertzberg, E. L., and R. V. Skibbens (1984) A protein homologous to the 27,000 dalton liver gap junction protein is present in a wide variety of species and tissues. Cell 39: 61-69.

Hertzberg, E. L., and D. C. Spray (1985) Studies of gap junctions. Biochemical analysis and use of antibody probes. In Gap Junctions, M. V. L. Bennett and D. C. Spray, eds., pp. 57-65, Cold Spring Harbor Laboratories, NY.

Hodgkin, A. L., and B. Katz (1949) The effect of sodium ions on the electrical activity of the giant axon of the squid. J. Physiol. (Lond.) 108: 37-77.

Iwatsuki, N., and O. H. Petersen (1979) Pancreatic acinar cells: The effect of carbon dioxide, ammonium chloride, and acetylcholine on intercellular communication. J. Physiol. (Lond.) 291: 317-326.

Johnston, M., S. Simon, and F. Ramon (1980) Interaction of anesthetics with electrical synapses. Nature $286: 498-500$.

Kaczmarek, L., M. Finbow, J. P. Revel, and F. Strumwasser (1979) The morphology and coupling of Aplysia bag cells within the abdominal ganglion and in cell culture. J. Neurobiol. 10: 535-550.

Kandel, E. (1976) Cellular Basis of Behavior, Freeman, San Francisco.

Knowles, W. D., P. G. Funch, and P. A. Schwartzkroin (1982) Electrotonic and dye coupling in hippocampal CAl pyramidal cells in vitro. Neuroscience 7: 1713-1722.

Levitan, I., and S. Barondes (1974) Octopamine- and serotonin-stimulated phosphorylaion of specific protein in the abdominal ganglion of Aplysia californica. Proc. Natl. Acad. Sci. USA 71:1145-1148.

Loewenstein, W. R. (1981) Junctional intercellular communication. The cell-to-cell membrane channel. Physiol. Rev. 61: 829-911.

Macagno, E. R., J. Muller, W. B. Kristan, S. A. DeRiemer, R. Stewart, and B. Granzow (1981) Mapping of neuronal contacts with intracellular injection of horseradish peroxidase and Lucifer Yellow in combination. Brain Res. 217: 143-149.

Margiotta, J. F., and B. Walcott (1983) Conductance and dye permeability of a rectifying electrical synapse. Nature 305: 52-55.

Muller, K. (1981) Synapses and synaptic transmission. In Neurobiology of the Leech, K. J. Muller, J. G. Nicholls, and G. S. Stent, eds., pp. 89-91, Cold Spring Harbor Laboratories, NY.

Murphy, A. D., R. D. Hadley, and S. B. Kater (1983) Axotony-induced parallel changes in electrical and dye coupling between identified neurons in Helisoma. J. Neurosci. 3: 1422-1429.

Nicholls, J. G., and D. Purves (1972) A comparison of chemical and electrical synaptic transmission between single sensory cells and a motoneurone in the central nervous system of the leech. J. Physiol. (Lond.) 225: 637-656.

Nicholson, B. J., L. J. Takemoto, M. W. Hunkapillar, L. E. Hood, and J. P. Revel (1983) Differences between liver gap junction protein and lens MIP 26 from rat. Cell 32: 967-978.

Ohme, M., and W. Simon (1976) Microelectrodes for potassium ions based on a neutral carrier and comparison of its characteristics with a cation exchange sensor. Anal. Chim. Acta 86: 21-25.

Provaznik, M., J. L. Ribas, and J. L. Parker (1979) Rhombic particle arrays in gill epithelium of a mollusc Aplysia californica. Tissue Cell 11: 337-344.

Rayport, G., and R. Kandel (1980) Developmental modulation of an identified electrical synapse: Functional coupling. J. Neurophysiol. 44: 555-567.

Renkin, E. M. (1955) Filtration, diffusion and molecules sieving through porous cellulose membranes. J. Gen. Physiol. 38: 225-243.

Revel, J. P., B. J. Nicholson, and S. B. Yancey (1985) Chemistry of gap junctions. Annu. Rev. Physiol. 47: 263-279.

Roos, A., and W. F. Boron (1981) Intracellular pH. Physiol. Rev. 61: $297-440$.

Roubos, E. W., J. P. T. M. Van Leewen, and A. Maijers (1985) U1trastructure of gap junctions in the central nervous system of Lymnea stagnalis with particular reference to electrotonic coupling between neuroendocrine caudodorsal cells. Neuroscience 14: 711-721.

Safranyos, R., and S. Caveney (1985) Rate of diffusion of fluorescent molecules via cell-to-cell membrane channels in a developing tissue. J. Cell Biol. 100: 736-747.

Safranyos, R., D. C. Spray, and M. V. L. Bennett (1986) Electrical and dye coupling at a developmental compartment boundary. J. Cell Biol. 103: 363a.

Schuetze, S. M., and D. A. Goodenough (1982) Dye transfer between cells of the embryonic chick lens becomes less sensitive to $\mathrm{CO}_{2}$ treatment during development. J. Cell Biol. 92: 694-705.

Schwartzmann, G., H. Wiegandt, B. Rose, A. Zimmerman, D. BenHaim, and W. R. Loewenstein (1981) Diameter of the cell-to-cell 
junctional membrane channels as probed with neutral molecules. Scicncc 213: 551-553.

Shapiro, E., V. F. Castellucci, and E. R. Kandel (1980) Presynaptic membrane potential affects transmitter release in an identified neuron in Aplysia by modulating the $\mathrm{Ca}^{2+}$ and $\mathrm{K}^{+}$currents. Proc. Natl. Acad. Sci. USA 77: 629-633.

Spray, D. C., and M. V. L. Bennett (1985) Physiology and pharmacology of gap junctions. Annu. Rev. Physiol. 47: 281-303.

Spray, D. C., A. L. Harris, and M. V. L. Bennett (1981a) Equilibrium properties of a voltage dependent junctional conductance. J. Gen. Physiol. 77: 75-94.

Spray, D. C., A. L. Harris, and M. V. L. Bennett (1981b) Gap junctional conductance is a simple and sensitive function of Intracellular pH. Science 211: 712-715.

Spray, D. C., R. L. White, V. Verselis, and M. V. L. Bennett (1985) Gencral and comparative physiology of gap junction channels. In Gap Junctions, M. V. L. Bennett and D. C. Spray, eds., pp. 139-153, Cold Spring Harbor Press, NY.

Spray, D. C., R. D. Ginzberg, E. A. Morales, Z. Gatmaitin, and I. M. Arias (1986) Electrophysiological properties of gap junctions between dissociated pairs of rat hepatocytes. J. Cell Biol. 103: 135-144. Stanfield, P. R. (1983) Tetraethylammonium ions and the potassium permeability in excitable cells. Rev. Physiol. Biochem. Pharmacol. 97: 1-67.

Thomas, R. C. (1974) Intracellular pH of snail neurones measured with a new pH-sensitive glass microelectrode. J. Physiol. (Lond.) 238: 159-180.

Turin, L., and A. E. Warner (1978) Carbon dioxide reversibly abolishes ionic communication between cells of early amphibian embryo. Nature 270: 56-57.

Verselis, V., D. C. Spray, R. L. White, and M. V. L. Bennett (1986a) Comparison of gap junctional conductance and permeability among early embryonic cells of frog, fish and squid. Biophys. J. 49: 203a.

Verselis, V., R. L. White, D. C. Spray, and M. V. L. Bennett (1986b) Gap junctional conductance and permeability are linearly related. Science 234: 461-464.

Warner, A. E., and P. A. Lawrence (1982) Permeability of gap junctions at the scgmental border in insect cpidermis. Cell 28: 243-252.

Waziri, R. (1969) Electrical transmission mediated by an identified cholinergic neuron of Aplysia. Life Sci. 8: 469-476.

Zimmerman, A. L., and B. Rose (1985) Permeability properties of cell-to-cell channels: Kinetics of fluorescent tracer diffusion through a cell junction. J. Membr. Biol. 84: 269-283. 